\title{
Controlling Offsite Movement of Agricultural Chemical Residues: Alfalfa
}

TERRY PRICHARD, University of California Cooperative Extension Water Management Specialist; RACHAEL FREEMAN LONG, University of California Cooperative Extension Farm Advisor, Yolo County; MICK CANEVARI, University of California Cooperative Extension

Farm Advisor Emeritus, San Joaquin County; and LAWRENCE

J. SCHWANKL, University of California Cooperative Extension Irrigation Specialist Emeritus, Kearney Agricultural Research and Extension Center

\section{INTRODUCTION}

-his publication provides growers of alfalfa with information on farming practices that can help reduce the occurrence of organophosphate and synthetic pyrethroid pesticides in surface water, including streams, lakes, ponds, rivers, and drainage ditches. It describes the current regulatory approach to surface water protection; gives background information on the safe and effective use of pesticides, integrated pest management, and handling runoff water; and demonstrates the self-assessment of the potential risk of offsite movement of an insecticide using flowcharts for specific management practices and field conditions in alfalfa. The risk self-assessment focuses on issues that affect either the number of pesticide applications containing certain active ingredients or the offsite movement of pesticides as drift, attached to sediment, or in water that carries pesticide active ingredients. The publication concludes with researchbased management practices that mitigate the risk that pesticide residues will leave the site of application and enter surface water.

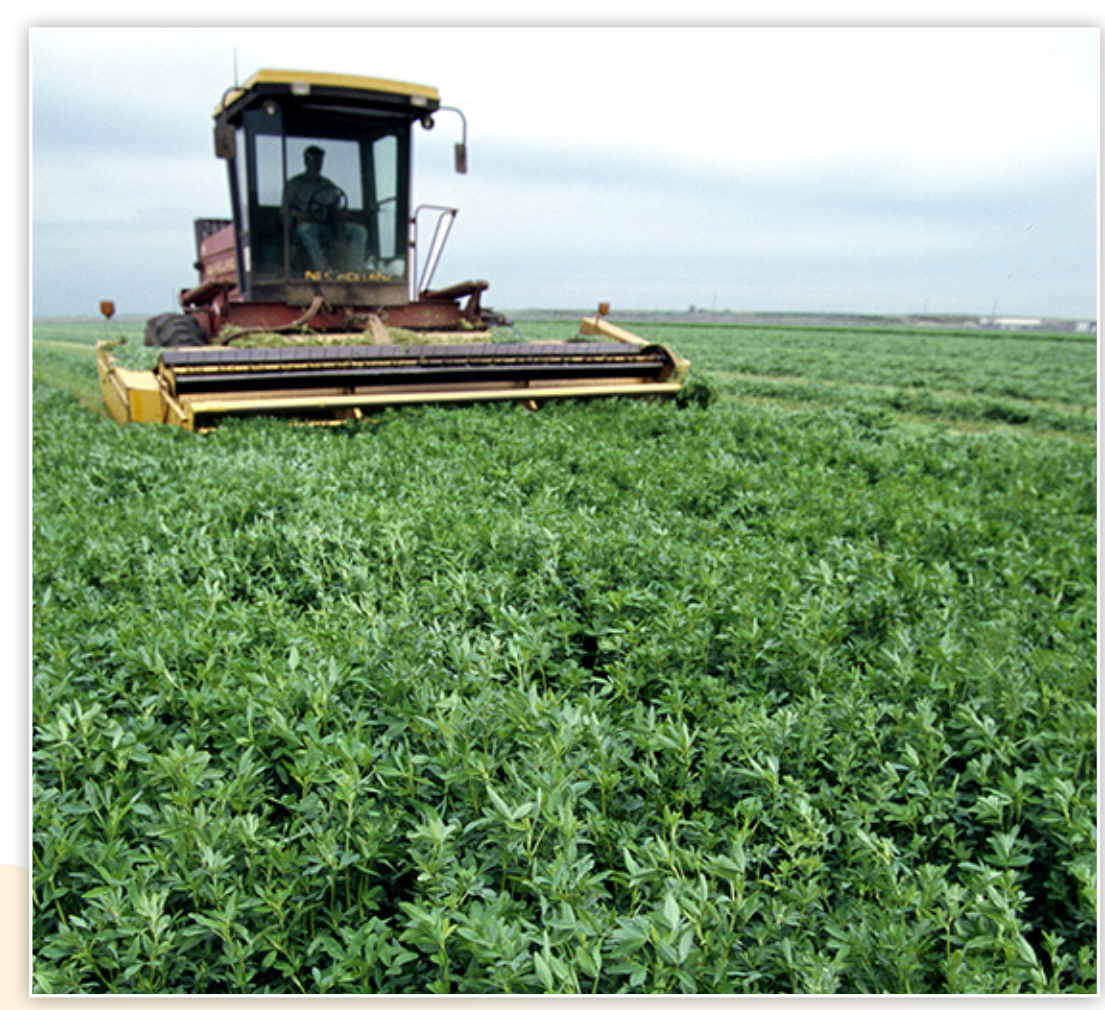

Photo by Suzanne Paisley 
More detailed information on implementation of many of these practices is available from sources cited throughout (see the references at the end of the publication). For assistance in determining which practices would be best for your operation or how to implement them, please contact your local UC Cooperative Extension farm advisor.

\section{Why Is This Publication Needed?}

The Central Valley occupies about $40 \%$ of the land area in California and provides much of the state's agricultural production. Maintaining this productivity resulted in the use of about 119 million pounds of pesticides in 2008 alone (PAN 2008). Water quality in the Central Valley's rivers and streams has been impacted in part due to pesticide movement from agricultural lands. The impaired water bodies recently proposed for listing under the Clean Water Act Section 303(d) include nearly a hundred water body segments in which impairment was due to agriculture. Agriculture is identified as the likely cause of impairment more often than any other pollution source in the state.

Agricultural pesticides reach surface water directly as spray drift or indirectly through irrigation or storm water runoff from treated fields, vineyards, and orchards. Runoff water may transport pesticides in dissolved form or as residues that adhere to soil particles. Among the pollutants often attributed to agriculture is the organophosphate insecticide chlorpyrifos. To indicate the extent of the problem, California agriculture uses 1,349,000 pounds of chlorpyrifos annually, more than any other insecticide (PAN 2008). Approximately half of the 303(d)-listed water body segments impaired due to agriculture in the Central Valley are impaired in whole or in part by chlorpyrifos.

The total maximum daily load (TMDL) is a calculation of the maximum amount of a pollutant that a water body can receive and still meet water quality standards. The presence of chlorpyrifos in surface water and its toxicity to aquatic life has been responsible for multiple TMDL projects in California, including one for the San Joaquin River, another for the Sacramento-San Joaquin Delta, and many others in locations where the TMDL definition process is less developed. In one study, chlorpyrifos was responsible for mortality to the test organism Ceriodaphnia dubia in seven of ten toxic samples (de Vlaming et al. 2004).

Synthetic pyrethroids are also emerging as a concern. Pyrethroids are a cause for 303 (d) listing in about $10 \%$ of agriculture-impaired water bodies in California. In a study of toxicity of sediments collected from agricultural waterways, 54 out of 200 sediment samples caused acute toxicity to the test organism Hyalella azteca, and pyrethroids were responsible for the toxicity in $61 \%$ of those cases (Weston et al. 2009). Chlorpyrifos was the second-most-common contributor to toxicity, responsible for toxicity in $20 \%$ of the samples. Recent data also indicate that pyrethroids are present at toxic levels in the water column of irrigation tailwater (runoff at the end of a field) samples. In a study just completed, the pyrethroid lambda-cyhalothrin was responsible for toxicity to $H$. azteca in three out of six toxic samples collected at California agricultural pump stations where tailwater was being returned to nearby rivers; chlorpyrifos was responsible in the remaining three samples (Weston and Lydy 2010). As analyses of environmental samples for pyrethroids become more frequent, it is likely that the water quality effects of pyrethroids will be even more broadly recognized.

The continued use of these effective agricultural pesticides depends on implementing measures to prevent the offsite movement of pesticide residues into surface water. Table 1 gives the active ingredients and trade names for insecticides used in alfalfa production with reported use over 500 pounds of active ingredient in California during 2008. Organophosphates and pyrethroids represent about $83 \%$ of this list, with chlorpyrifos, an organophosphate, being the highest-used product based on pounds applied per year. 
Table 1. Insecticides used on alfalfa in California, 2008

\begin{tabular}{|l|l|l|l|}
\hline $\begin{array}{l}\text { Active ingredient } \\
\text { common name }\end{array}$ & Trade name* & Use (lb/yr) & Chemical class \\
\hline chlorpyrifos & Lorsban, Lock -On & 187,460 & organophosphate \\
\hline malathion & Malathion & 105,111 & organophosphate \\
\hline dimethoate & Dimethoate & 53,167 & organophosphate \\
\hline indoxacarb & Steward & 28,951 & oxadiazine \\
\hline naled* & Dibrome & 17,905 & organophosphate \\
\hline methomyl & Lannate & 17,645 & carbamate \\
\hline methamidophos* & Monitor & 14,436 & organophosphate \\
\hline lambda-cyhalothrin & Warrior & 10,957 & pyrethroid \\
\hline methidathion* & Supracide & 9,699 & organophosphate \\
\hline methoxyfenozide & Intrepid & 7,879 & diacylhydrazine \\
\hline bacillus thuringiensis & Dipel, Javelin, XenTari & 6,954 & biological \\
\hline formetanate & Carzol & 6,489 & carbamate \\
\hline hydrochloride & Mustang & 4,009 & pyrethroid \\
\hline zeta-cypermethrin & Pounce, Ambush & 3,262 & pyrethroid \\
\hline permethrin & Baythroid & 2,527 & pyrethroid \\
\hline beta-cyfluthrin & Capture & 1,397 & pyrethroid \\
\hline bifenthrin & Sevin & 507 & carbamate \\
\hline carbaryl & & & \\
\hline Source: Californa & & & \\
\hline
\end{tabular}

Source: California Department of Pesticide Regulation

Note: *Section 24(c) for alfalfa seed production.

Some of these pesticides may no longer be registered for alfalfa, so read the label as required by law.

\section{Current Regulatory Approach to Surface Water Protection}

All growers farm under a regulatory requirement not to pollute surface and groundwater. Water leaving agricultural lands as irrigation or storm water runoff can contain pesticide residues, sediment, and nutrients. These discharges in the Central Valley are regulated by California’s Central Valley Regional Water Quality Control Board under the Irrigated Lands Regulatory Program.

Essentially, the board enforces the California Water Code of 1969 and the federal Clean Water Act of 1972. To this end, the water board has established surface water quality standards in each watershed basin plan and has enforced waste discharge requirements.

\section{The Ag Waiver}

In 1982 the Central Valley water board adopted the resolution "Waiving Waste Discharge Requirements for Specific Types of Discharge." The resolution contained 23 categories of waste discharges, including irrigation return flows and storm water runoff from agricultural lands. The resolution also listed the conditions required to comply with the waiver; hence the term "Conditional Ag Waiver." Due to a shortage of resources at the time, the water board did not impose measures to verify compliance with these conditions.

The waiver, set to sunset in 2003, was amended by adopting two conditional waivers for discharges from irrigated lands. One waiver was for coalition groups of individual dischargers to comply with the California Water Code and water board regulations. The second was for growers to comply as individual entities. To be covered by the waivers, the coalition or individual must have filed with the water board by November 1, 2003, a Notice of Intent and General Report that contained specific information about their farm and must have adhered to a plan and timeline that includes, among other things, a surface water monitoring plan.

\section{Water Quality Coalitions}

Water quality coalitions are generally formed by growers on a subwatershed basis. A few coalitions were formed for a specific commodity. The San Joaquin County and Delta Water Quality Coalition, for example, encompasses all of San Joaquin County and portions of Contra Costa, Alameda, and Calaveras Counties. The coalition includes about 500,000 acres of irrigated lands and represents 4,500 individual members. The coalition monitors and analyzes the water quality of subwatersheds in surface water and facilitates the implementation of management plans. Coalitions provide outreach and support to growers in response to water quality exceedances at subwatershed monitoring sites in order to enhance the water quality of affected water bodies. 


\section{Water Quality Monitoring}

The San Joaquin County and Delta Water Quality Coalition currently monitors water quality at numerous sites in large and small subwatersheds in the coalition watershed. Water samples are collected monthly, and sediment samples are collected twice per year. During 2008, the level of a material being monitored exceeded water quality standards many times. At some locations, as many as $40 \%$ of the samples exceeded water quality standards for pesticide residues (Karkoski 2008). When more than one exceedance of water quality standards occurs for any contaminant, the coalition must develop a management plan to address it. In addition, any single exceedance of either chlorpyrifos or diazinon triggers the requirement for a management plan.

\section{Water Quality Management Plans}

The overall goal of water quality management plans, whether developed by individuals or coalition, is to reduce agricultural impacts on water quality in the plan area. Management plans evaluate the frequency and magnitude of exceedances and prioritize locations for outreach. To achieve the goal of improving water quality, a management plan must include

- identification of the source of constituents that impair water quality

- outreach to growers about irrigation and dormant-season management practices that protect water quality

- evaluation of water quality improvements by monitoring and implementing management practices

Under the management plan landowners or growers must

- help the coalition succeed by participating in efforts to solve water quality impairments identified through water quality monitoring

- stay informed by reading mailings and updates and responding as necessary

- attend grower water quality information meetings

- implement management practices that mitigate the identified water quality concerns

\section{How to Use This Publication}

This publication should be used in a two-step process. The first step is to make a risk evaluation of field conditions or operations to identify farming practices that may influence the risk of offsite pesticide movement. This risk evaluation is made using a series of flowcharts. Once avenues of possible pesticide movement from a particular field are identified in the first flowchart, succeeding flowcharts help identify specific conditions and operations that can reduce offsite movement. When followed systematically from beginning to end, the flowcharts guide the user through a step-bystep evaluation of a farming operation to identify potential problem areas. The section "Overview of Risk Evaluation" below describes how to use the flowcharts and contains sample sections of two flowcharts. The complete flowcharts can be found at the end of this publication.

The second step in the process is to understand and implement management practices that address problem areas. These management practices are divided into three broad areas: integrated pest management, water and soil management, and managing runoff water.

\section{Integrated Pest Management}

Use integrated pest management (IPM) practices and handle and apply pesticides correctly. IPM is an ecosystem-based strategy that focuses on long-term prevention of pests or their damage through a combination of techniques such as biological control, habitat manipulation, modification of cultural practices, and use of resistant varieties. Pesticides are used only after monitoring indicates that they are needed according to established guidelines, and treatments are made with the goal of removing only the target organism. Coupling IPM techniques with proper pesticide selection, handling, and application can mitigate the offsite movement of pesticide residues. These practices should be the foundation of any water quality protection program. Implementing at least some of them can also reduce risks to human health, beneficial and nontarget organisms, and the environment. 


\section{Water and Soil Management}

Use soil and water management practices that reduce runoff potential. Runoff occurs when irrigation or rainfall delivers water faster than it can enter the soil. Runoff water can carry dissolved pesticides or transport eroded soil particles that have pesticides adsorbed on them into waterways. To help ensure that irrigation water needs are met and runoff is kept to a minimum, it is important to select the proper irrigation method, system design, and operation. Soil management practices that promote water infiltration and irrigation efficiency include a reduction in tillage, especially when wet, to avoid compaction; increasing soil organic matter; grading the soil slope to accommodate irrigation uniformity; adding soil amendments as needed; and growing cover crops during the off-season to reduce winter rainfall runoff.

\section{Managing Runoff Water}

If IPM and water and soil management do not adequately address poor water quality, techniques for physically intercepting, recycling, or chemically treating runoff water can reduce the offsite transport of pesticides in water.

\section{Overview of Risk Evaluation}

For a quick overview of the risk evaluation process, we will consider a sample alfalfa field to illustrate how the flowcharts and management information in this publication can be used to identify and correct the offsite movement of an insecticide. A more detailed discussion of this case study is presented in the section. The thick, shaded arrows in the flowcharts indicate the logical progression in considering the most cost effective management practices.

Crop: Alfalfa, 40 acres

Site conditions:

Topography: $0.15 \%$ slope

Soil: Hollenbeck silty clay loam soil which tends to crust, thus limiting the water infiltration rate.

Irrigation system: Border-check irrigation, checks 53 feet wide

Irrigation Runoff: Runoff is about $17 \%$ of the applied water.

\section{Irrigation water: $\mathrm{pH} 7.5, \mathrm{EC} 0.2 \mathrm{dS} / \mathrm{m}$}

Drainage: Runoff moves to a drainage ditch at end of the field, then enters a larger creek.

Pesticide mixing and loading: A pesticide mixing and Pest:

loading area is located 40 -feet from the drainage ditch.

Egyptian alfalfa weevil, 20 per sweep

\section{Using the Flowcharts}

A risk assessment would begin with Flowchart 1, Offsite Movement Risk, which considers possible routes by which pesticide could move off the field and the operations or conditions that may contribute to the movement. The three possible areas of concern are irrigation runoff, spray drift, and storm water runoff.

\section{- Irrigation runoff risk (fig. 1).}

Pesticides applied

to the field may be carried in the runoff that occurs during surface irrigation after a pesticide application. The path for this type of risk in Flowchart 1 leads to Flowchart 3.

\section{Figure 1. Excerpt from} Flowchart 1, showing path of irrigation runoff risk for sample tomato field.

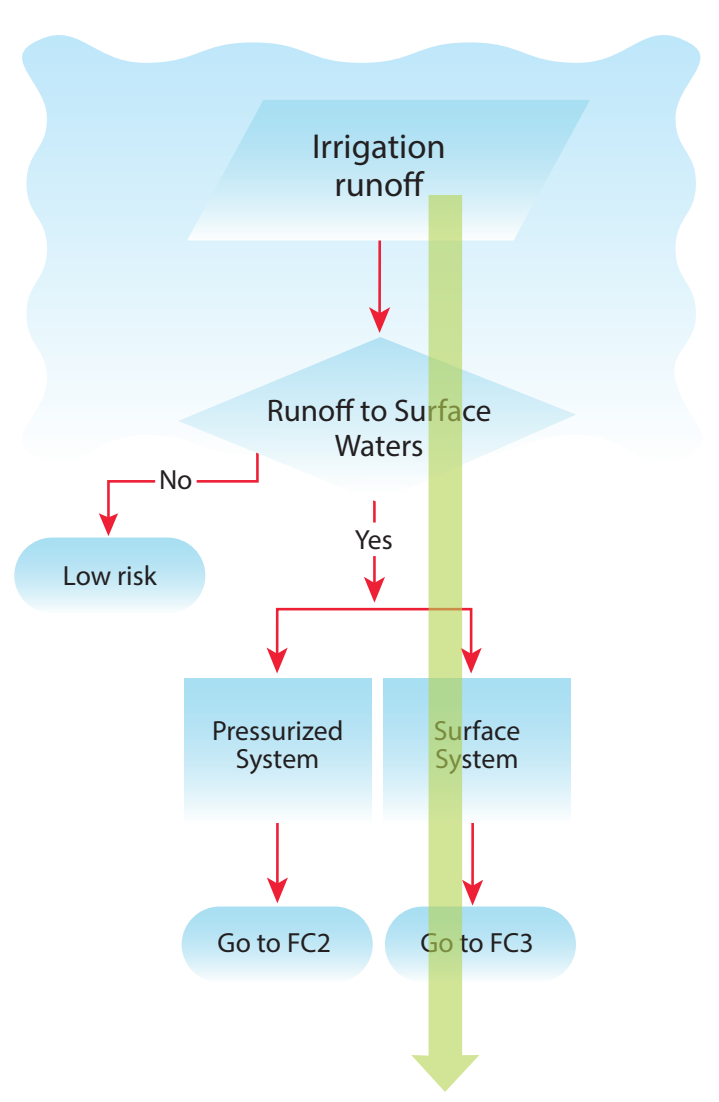




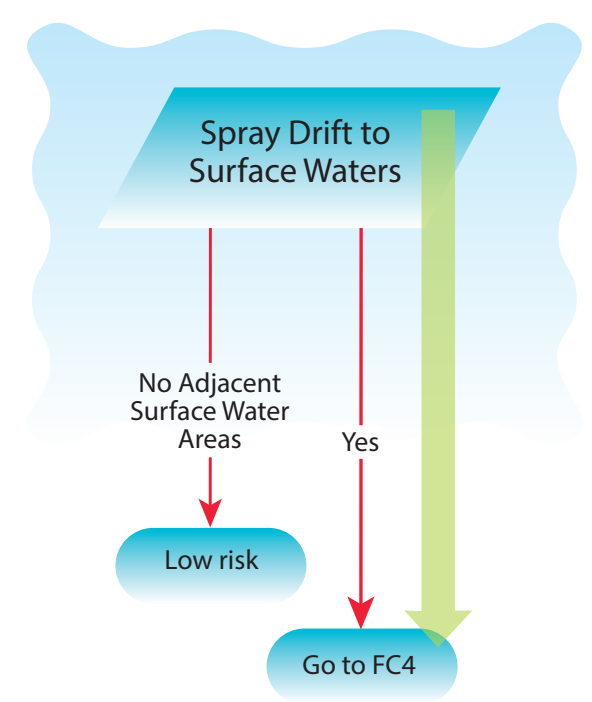

Figure 1. Excerpt from flowchart 1, showing spray drift risk.

Figure 3. Excerpt from Flowchart 1, showing stormwater runoff risk.

\section{- Application near surface waters} (spray drift) risk (fig. 2). During spray applications, pesticides may drift into the drainage ditch along the edge of the field. The path for this type of risk leads to Flowchart 5.

- Storm water runoff risk (fig. 3). Pesticides may be carried in storm water runoff in dissolved form and adsorbed to sediments. The risk of transport in runoff is generally low for pesticide applications made during the crop season. However, persistent insecticides can contribute to surface water degradation during storm water runoff after the crop season. The path for this type of risk leads to Flowchart 4.

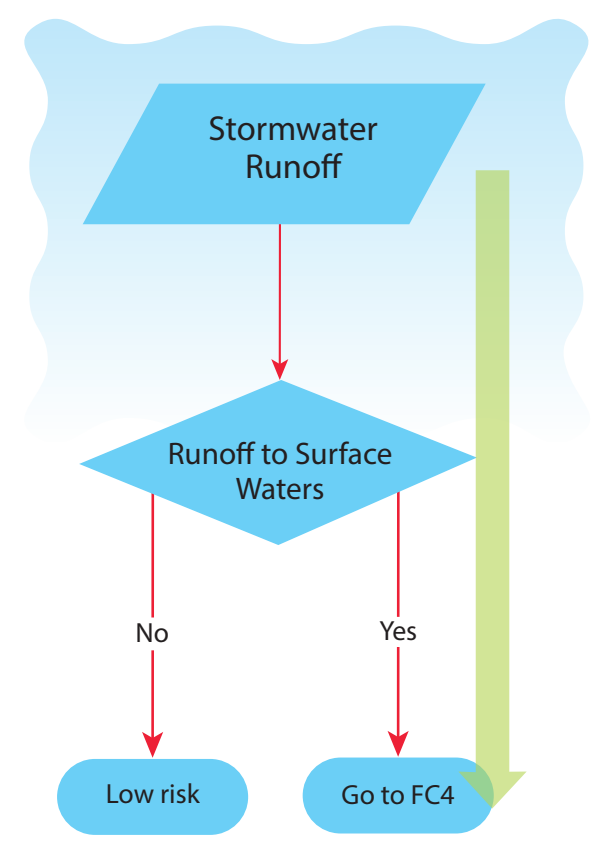

\section{Management Practices that Reduce Surface Water Pesticide Contamination}

\section{Integrated Pest Management}

The University of California Integrated Pest Management Program's website, http://ucipm.ucdavis.edu, defines IPM as

an ecosystem-based strategy that focuses on long-term prevention of pests or their damage through a combination of techniques such as biological control, habitat manipulation, modification of cultural practices, and use of resistant varieties. Pesticides are used only after monitoring indicates they are needed according to established guidelines, and treatments are made with the goal of removing only the target organism. Pest control materials are selected and applied in a manner that minimizes risks to human health, beneficial and non-target organisms, and the environment.

IPM is a systematic approach to pest management. The decision process includes

- selecting varieties that are well adapted to local conditions and have a high degree of pest resistance

- using certified seed that is nearly free of weeds, insects, and diseases

- identifying the pest

- understanding pest life cycles and conditions conducive to infestation

- monitoring for the presence, location, and abundance of pests and their natural enemies

- treating when established action thresholds (economic, aesthetic, tolerance) are reached

- considering multiple tactics for pest suppression-biological, cultural, and chemical-and selecting the lowest-risk practical and effective approach

- evaluating results 
For more information on IPM management actions, see

- UC IPM Pest Management Guidelines for Alfalfa, http://www.ipm. ucdavis.edu/PMG

- UC IPM Year Round Program for alfalfa hay, with annual checklist, http://www.ipm.ucdavis.edu/PMG/C001/m001yi01.html

- Integrated Pest Management for Alfalfa Hay (Flint 1981)

- UC Irrigated Alfalfa Management Publication http://alfalfa. ucdavis.edu

- licensed pest control and crop advisers

- UC IPM advisors and farm advisors

\section{Selecting Pesticides That Reduce Water Quality Risks}

Knowledge of how pesticides move and degrade in the environment is useful selecting the best product to use. Pesticides and pesticide

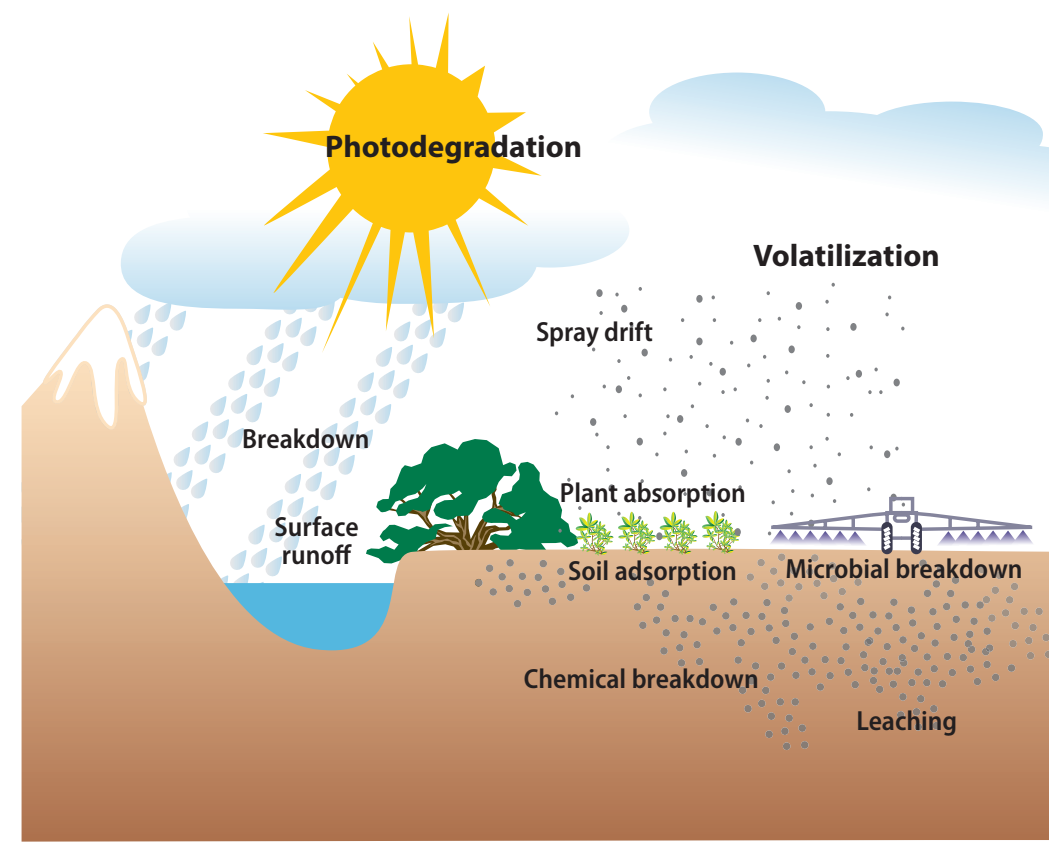

Figure 4. Pesticide fate processes. residues can move along several different pathways, depending on properties of the pesticide, the application method, and conditions at the application site (fig. 4). This movement is a complex process that, combined with several other factors, influences a pesticide's fate and potential impact on water quality. From the perspective of surface water management, keeping the pesticide on or in the soil by preventing runoff is the most desirable option.

Active ingredients in pesticides used on alfalfa vary in their water solubility, soil adsorption, and half-life. Pesticides with high water solubility can move directly in runoff water, while those adsorbed to soil sediments (which generally have low water solubility) move with the sediment. Half-life is an indication of the pesticide's persistence in the environment, and it is usually measured in the number of days it takes for the pesticide to degrade to one half its original concentration. The soil adsorption coefficient (Koc) can be considered an index of pesticide mobility. The USDA Natural Resources Conservation Service has a model (WIN-PST) that takes these characteristics into consideration in determining a pesticide's tendency to move in dissolved form with water or to move while adsorbed to sediments. A pesticide's potential to move offsite, either in solution or with the soil, is categorized as high, intermediate, or low (table 2).

Aquatic toxicity rankings were extracted from the U.S. EPA ECOTOX database (EPA 2007). The toxicity for EPA indicator species was then used to rank the overall aquatic risk (Long et al. 2005). A pesticide's overall likelihood (risk) to cause a negative impact on surface water quality is a product of the runoff potential and the aquatic toxicity of the pesticide. Table 2 indicates this relationship for commonly used insecticides in alfalfa production (products without a risk category are new or have not yet been categorized in this system). The table can be used to select pesticides based on the risk of offsite movement to surface water. Changing from one pesticide to another in the same class or in a different class can significantly reduce the environmental risk of offsite movement. 
Table 2. Insecticides registered for use on alfalfa in California (2011), their potential to move in solution or as adsorbed particles, and their overall pesticide runoff risk (some of these pesticides may no longer be registered for use in alfalfa, so read the pesticide label as required by law).

\begin{tabular}{|c|c|c|c|c|c|}
\hline $\begin{array}{l}\text { Insecticide active } \\
\text { ingredient (common } \\
\text { name) }\end{array}$ & $\begin{array}{l}\text { Trade } \\
\text { name }\end{array}$ & Chemical class & $\begin{array}{l}\text { Solution } \\
\text { runoff } \\
\text { potential* }\end{array}$ & $\begin{array}{l}\text { Adsorption } \\
\text { runoff } \\
\text { potential }^{\dagger}\end{array}$ & $\begin{array}{l}\text { Overall } \\
\text { runoff risk }\end{array}$ \\
\hline Bacillis thuringiensis & $\begin{array}{l}\text { Dipel, } \\
\text { Javelin, } \\
\text { XenTari }\end{array}$ & biological & low & low & low \\
\hline carbaryl & Sevin & carbamate & intermediate & low & moderate \\
\hline chlorantraniliprole & Coragen & diamide & low & high & moderate \\
\hline chlorpyrifos & $\begin{array}{l}\text { Lorsban, } \\
\text { Lock-On }\end{array}$ & organophosphate & high & intermediate & very high \\
\hline cyfluthrin & Baythroid & pyrethroid & low & intermediate & high \\
\hline dimethoate & Dimethoate & organophosphate & low & low & low \\
\hline $\begin{array}{l}\text { formatanate } \\
\text { hydrochloride } \\
\text { (only for seed alfalfa } \\
\text { production) }\end{array}$ & Carzol & carbamate & & & \\
\hline indoxacarb & Steward & oxadiazine & low & intermediate & \\
\hline lambda-cyhalothrin & Warrior & pyrethroid & low & intermediate & high \\
\hline malathion & Malathion & organophosphate & intermediate & low & moderate \\
\hline methamidophos ${ }^{\S}$ & Monitor & organophosphate & low & low & low \\
\hline methidathion ${ }^{\S}$ & Supricide & organophosphate & intermediate & low & moderate \\
\hline methomyl & Lannate & carbamate & intermediate & low & moderate \\
\hline methoxyfenozide & Intrepid & diacylhydrazine & high & intermediate & low \\
\hline naled $^{\S}$ & Dibrome & organophosphate & low & low & low \\
\hline permethrin & $\begin{array}{l}\text { Ambush, } \\
\text { Pounce }\end{array}$ & pyrethroid & low & high & high \\
\hline phosmet & Imidan & organophosphate & intermediate & low & moderate \\
\hline zeta-cypermethrin & Mustang & pyrethroid & low & high & high \\
\hline
\end{tabular}

Source: Long et al. 2005

Notes:

"Likelihood that the active ingredient will transport from the area of treatment as dissolved chemical in runoff.

t Likelihood that the active ingredient will transport from the area of treatment as attachment to soil or sediment particles in runoff.

FOverall likelihood to cause negative impact on surface water quality as a product of the runoff potential and the aquatic toxicity of the pesticide.

\$24(c) registration for alfalfa seed.

\section{Pesticide Handling Practices That Reduce Water Quality Risks}

The risk of offsite pesticide movement is great during mixing and loading due to the possible spillage of undiluted pesticides. Care must be taken to ensure that all of the pesticide goes in the tank. Partially fill the tank with water prior to adding the pesticide to prevent high-strength materials from entering spray lines. Agitation and the use of a bypass can assist good mixing. Avoid overfilling the tank, because spillage can move offsite aided by cleanup water. Mix and load farther than 50 feet from sensitive areas (e.g., open surface water). Use a greater distance if there is a potential for movement in the direction of the sensitive area. Triple-rinse pesticide containers and pour the rinsate into the sprayer tank for use on the field. Also apply tank rinse water to the field. Using a concrete mixing and loading pad with a catchment sump is a good way to reduce risks from mixing and loading near surface water sources.

\section{Pesticide Application Practices That Reduce Offsite Pesticide Movement}

\section{Minimizing spray drift}

Drift is the physical movement of pesticide droplets or particles through the air from the target site to any off-target site at the time of pesticide application or soon thereafter. All ground and aerial applications produce some drift. How much drift occurs depends on the formulation of the material applied, how the material is applied, the volume used, prevailing weather conditions at the time of application, and the size of the application. Drift can impact surface water quality through direct contact with open ditches or with surface water adjacent to the treated field.

Spray drift can be mitigated by management practices that reduce off-target drift. Application practices that take weather and other site conditions into consideration, have appropriately equipped delivery systems (low-drift nozzles), use appropriate product choice (low vapor pressure and low water solubility), and use buffer zones that can significantly reduce the risk of offsite movement of pesticides. 


\section{Application conditions}

- Do not apply pesticides under dead calm conditions, where drift can easily migrate, or in windy or gusty conditions; do not apply at wind speeds greater than $10 \mathrm{mph}$ (ideally not over $5 \mathrm{mph}$ ). Read the label for specific instructions.

- Apply pesticides early in the morning or late in the evening, when the air is usually calmer than during the day.

- Determine the wind direction and take it into account when deciding whether or how to make an application.

- Calibrate and adjust sprayers to accurately direct the spray into the canopy target.

- Delay treatments near ditches and surface water until the wind is blowing away from these and other sensitive areas.

- Do not spray during thermal inversions, when air closest to the ground is warmer than the air above it.

\section{Application equipment}

- Use the coarsest spray possible (250 to 400 microns or larger) while still obtaining good coverage and control. Droplet size is one of the most important factors affecting drift: the larger the droplet, the less drift.

- Use low-drift nozzles that produce larger droplets. Fitting a sprayer with air induction nozzles reduces spray drift up to $50 \%$ over standard nozzles.

- Verify that the expected spray pattern is being deposited.

- Service and calibrate spray equipment regularly.

- Check the system for leaks. Small leaks under pressure can produce very fine droplets. Large leaks contaminate soil that can be moved offsite by water.

- Use low pressure and spray volumes appropriate for the canopy size.

\section{Product choice}

- Choose an application method and formulation that are less likely to cause drift. After considering the drift potential of a product, formulation, or application method, it may become necessary to use a different product to reduce the chance of drift.

- Use drift control or drift reduction spray additives. These materials are generally thickeners designed to minimize the formation of droplets smaller than 150 microns. They also help produce a more consistent spray pattern and deposition.

- Use spray adjuvants, which can greatly reduce application volumes without compromising pesticide efficacy.

- Use the maximum spray volume per acre and low pressure.

\section{Buffer zones}

- Maintain adequate buffer zones around the treated site to ensure that pesticides do not drift onto sensitive areas. A buffer zone is the area between the waterway and where the pesticide is applied. Read the label to determine the size of buffer zone required as related to the active ingredient.

- Treat buffer zones with materials that pose the least risk to aquatic life.

- Change application method. Aerial application has a larger drift potential than ground application. When the risk of drift risk is present, changing to ground application requires a smaller buffer zone.

\section{Avoiding application times prone to risk}

Management practices to mitigate offsite movement risk include avoiding application when rain is predicted, especially when the soil is saturated by previous rainfall. Also, pesticides that require application after harvest are at risk of residue runoff when applied to saturated soil or when rainfall is predicted. Apply as near to harvest as possible.

\section{Irrigation Water Management Practices That Reduce Runoff}

Any reduction in runoff volume or decrease in the velocity of runoff flow can reduce the amount of both soluble and sedimentattached residues. Managing the irrigation to uniformly apply the correct amount of water to meet crop demand and to increase water infiltration rates can minimize runoff rates and overall runoff volumes. 
Irrigation management entails assessing crop water needs and applying irrigation water to supplement stored winter moisture.

Irrigation frequency and duration should ensure that enough water infiltrates to meet plant water needs while preventing water loss through runoff and deep percolation. The extent of runoff depends on several factors, including the slope or grade of an area, the texture and moisture content of the soil, the infiltration rate, and the amount and timing of irrigation or rainfall. Runoff that contains pesticides can cause direct injury to nontarget species, harm aquatic organisms in streams and ponds, and lead to groundwater contamination.

Two basic types of irrigation systems are used in alfalfa production: surface systems (border check) and pressurized systems (sprinkler). Each has distinct cultural, cost, and offsite movement advantages and disadvantages. Some disadvantages can be overcome using specific management practices.

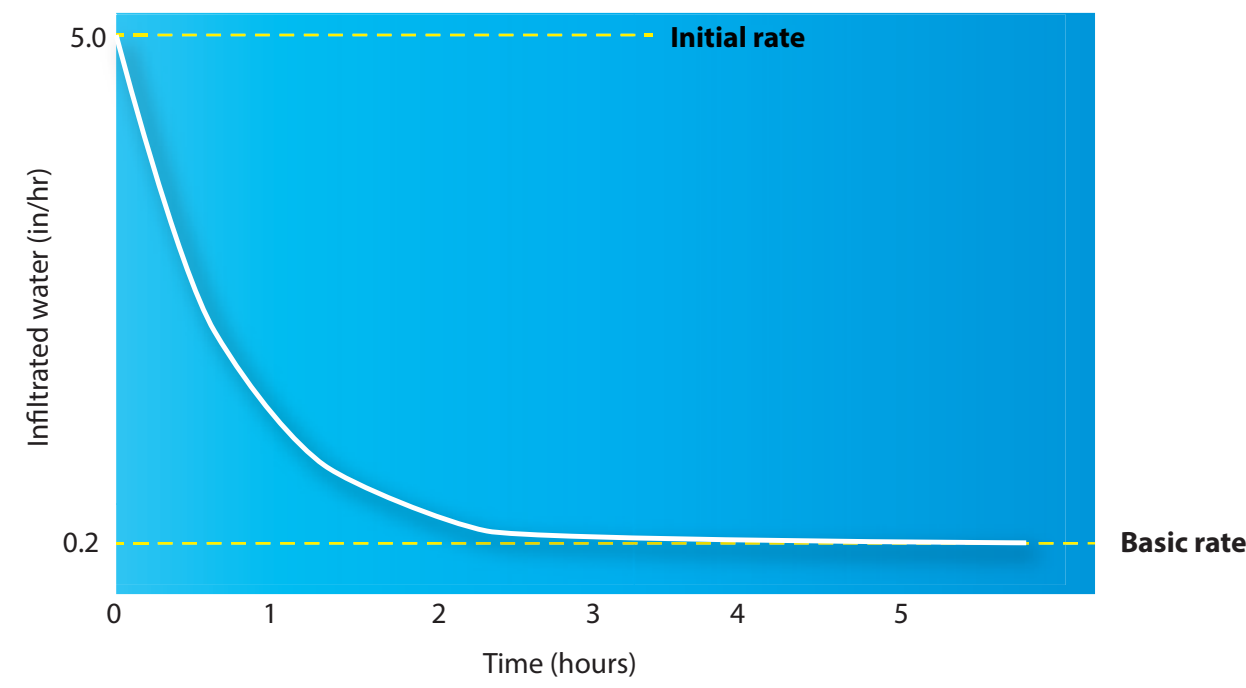

Figure 5. Typical water infiltration characteristics.

\section{Reducing runoff in surface irrigation systems}

Surface irrigation systems, such as border check irrigation, while being the simplest irrigation systems with regard to hardware, are the most difficult to manage properly. Control of runoff water is essential for controlling offsite movement of pesticides, sediments, and nutrients.

With border check irrigation, water is applied to the soil surface, and gravity moves the water across the field. Soil characteristics control both the rate at which water enters the soil and its distribution across the irrigated area. As irrigation begins, the rate at which water enters the soil is high, primarily because of soil dryness and easy access to the soil pores. As irrigation proceeds, the infiltration rate declines rapidly to a sustained rate (also called the basic rate). Figure 5 shows the typical relationship between the amount of water infiltrated into the soil and the duration of irrigation.

A soil's water intake characteristics depend on its physical and chemical composition as well as the chemical composition of the water. Irrigation water with very low salt content or high levels of sodium or bicarbonate can reduce infiltration rates. For more information, see "Reducing Runoff by Improving Water Infiltration," below.

In general, the objective of any irrigation system is to have water infiltrating for the same length of time in all parts of the field. This is difficult to accomplish with border check systems because it takes time for water to flow from the head of field down to the tail of the field. This "advance time" causes less water to be infiltrated toward the tail of the field.

In border check irrigation, a large amount of water remains on the soil surface during an irrigation. After irrigation cutoff, water remaining on the surface continues to infiltrate as it moves down slope until all the surface water disappears at the tail end of the field. The time from when the irrigation is cut off to when the water at the tail end of the field disappears is called the irrigation recession time. The difference between the advance time and recession time is the infiltration time. Measuring the distribution of infiltrated water in surface systems is difficult at best. The overall 
goal is to provide near equal opportunity time along the length of the check (Hanson and Schwankl 1995). The controlling factor for advance time is the inflow volume: more volume equals faster advance. The recession time is influenced by both the inflow rate (higher inflow rate yields more surface-stored water at the irrigation cutoff time) and the irrigation cutoff time (earlier cutoff results in less infiltration time at the tail of the field).

In general, keeping the checks as short as practical helps keep irrigation uniformity high. The tradeoff with short checks is an increase in labor cost, pipeline cost, and runoff volume. Tailwater return systems can increase the efficiency of border check irrigation and eliminate discharges. Limiting runoff after a reasonable uniformity has been achieved is an effective practice to reduce the continued movement of residues offsite. An irrigation runoff return or tailwater return system can capture runoff and return it to the irrigation inflow, to be applied to adjacent irrigation sets or another field. At sites with runoff risks to surface waters, changing from surface irrigation to pressurized irrigation is recommended when possible.

\section{Measuring applied water in surface systems}

One difficulty in managing surface irrigation systems is measuring the volume of water applied to the field. If water is supplied from a pump, a flow meter such as a propeller meter can be installed in the outlet pipe. Follow the manufacturer's recommended installation criteria to obtain accurate measurements. It is difficult to measure water supplied from an open ditch. Consult the irrigation district for help in getting a good estimate of the flow rate to the field.

The following formula may be used to determine the average volume of water applied to a field using a meter that indicates cubic feet per second (cfs):

$$
D=\mathrm{Q} \times \mathrm{T} \div \mathrm{A},
$$

where $D=$ depth of applied water (inches), $Q=$ flow rate into the field (cubic feet per second), $T=$ time required to apply water to the field (hours), and $A=$ acres irrigated. If the flow meter reads in gallons per minute (gpm) rather than in cubic feet per second, the conversion is $1 \mathrm{cfs}=449 \mathrm{gpm}$. For example, assume that flow $=4.45$ cfs $(2,000 \mathrm{gpm})$, irrigation duration $=8.6$ hours, and area $=8$ acres:

$$
\begin{gathered}
D=4.45 \mathrm{cfs} \times 8.6 \mathrm{hr} \div 8 \mathrm{ac} \\
=4.8 \text { inches }
\end{gathered}
$$

The depth of water obtained in the above formula should match the amount of water used by the crop since the last irrigation, which is roughly equivalent to evapotranspiration (ET) (see "Irrigation Scheduling to Meet Crop Requirements," below). Remember that some additional water should be applied because no irrigation system is $100 \%$ efficient; border check irrigation is generally less efficient than pressurized irrigation.

\section{Reducing runoff in pressurized irrigation systems}

Pressurized irrigation systems include wheel-line, hand-move, center-pivot, and linear-move systems. Buried drip systems, also a pressurized system, are extremely rare in alfalfa production due to important practical limitations, including system costs and maintenance and problems with rodent damage. Buried drip systems, also a pressurized system, are becoming more common with an interest in water conservation but have limitations with rodent damage. Wheel-line and hand-move systems are classified as periodic-move systems, while linear-move and center-pivots are considered continuous-move systems. Pressurized systems share the common trait of "designed in" uniformity that overcomes many of the disadvantages of border-check irrigation.

\section{Irrigation scheduling to meet crop water requirements}

Alfalfa yield is directly related to crop evapotranspiration (ET). Evapotranspiration is the sum of evaporation from the soil surface and plant water use (transpiration). Climatic factors affecting crop evapotranspiration include solar radiation, temperature, wind, and humidity. Plant and soil factors affecting evapotranspiration include plant type, stage of growth, health of the plant, and soil moisture. The seasonal ET of alfalfa varies by location in California; in the Central Valley, it ranges from 41 to 49 inches.

\section{Estimating water requirements}

Crop water use begins at a low level in spring when climatic conditions are mild, then gradually increases as the days lengthen 
and the weather warms, reaching a peak in mid-summer and decreasing as fall approaches. Water use is also influenced by alfalfa growth stage and harvest. Immediately after harvest, most of the water loss from the soil occurs by soil evaporation until alfalfa regrowth begins. The best way to estimate crop water use is to use climatic data and a specific crop's characteristics. Alfalfa ET can be estimated using the following formula:

$$
E T \mathrm{c}=E T_{\mathrm{o} \times} K_{\mathrm{c}}
$$

Where $\mathrm{ET}_{\mathrm{c}}$ is the crop water use, $\mathrm{ET}_{\mathrm{o}}$ is the reference evapotranspiration for a given area, and $\mathrm{Kc}$ is a crop coefficient.

Reference ET $\left(\mathrm{ET}_{\mathrm{o}}\right)$ information is available from a network of nearly 100 California Irrigation Management Information System (CIMIS) weather stations that provide daily reference evapotranspiration values. Two good web-based sources are the UC Statewide Integrated Pest Management website, http:||www.ipm. ucdavis.edu, and the California Department of Water Resources CIMIS website, http: $\ \backslash$ www.cimis.water.ca.gov. Some newspapers and irrigation districts also provide CIMIS $\mathrm{ET}_{0}$ data. The CIMIS program provides real-time (current) values. Historical, or longterm average, $\mathrm{ET}_{\mathrm{o}}$ can be more convenient than real-time $\mathrm{ET}_{\mathrm{o}}$ information and can be used to prepare an irrigation plan well ahead of the irrigation season. Table 3 gives historical daily $\mathrm{ET}_{\mathrm{o}}$ values for four Central Valley locations.

Crop coefficients for alfalfa have been experimentally determined and may be calculated based on canopy coverage. The coefficient depends on the growth stage of alfalfa. The $\mathrm{K}_{\mathrm{c}}$ is smallest after harvest, about 0.4 to 0.5 , and reaches a maximum of about 1.1 to 1.2 just prior to harvest (Hanson et al. 2008). A more practical method than accounting for changing $\mathrm{K}_{\mathrm{c}}$ conditions is to use an average value during the irrigation season as shown in table 4 . An example of a bi-weekly irrigation schedule for alfalfa in the Manteca area of California is presented in table 5. This schedule uses the basic inputs of $\mathrm{ET}_{\mathrm{o}}$ (table 3 ) beginning in April and the average crop coefficient (Table 4 ) to estimate the alfalfa water use $\left(\mathrm{ET}_{\mathrm{c}}\right)$.

Although water use can be calculated on any time scale (bi-weekly in the above example), the scheduling of alfalfa
Table 3. Historical crop evapotranspiration reference (in/day) for various California Central Valley locations

\begin{tabular}{|c|c|c|c|c|c|}
\hline \multicolumn{2}{|c|}{ Date } & \multirow{2}{*}{$\begin{array}{l}\text { Five } \\
\text { Points } \\
0.04\end{array}$} & \multirow{2}{*}{$\begin{array}{l}\text { Manteca } \\
0.04\end{array}$} & \multirow{2}{*}{$\begin{array}{l}\text { Davis } \\
0.03\end{array}$} & \multirow{2}{*}{$\begin{array}{l}\text { Durham } \\
0.03\end{array}$} \\
\hline & $1-15$ & & & & \\
\hline Jan & 16-31 & 0.05 & 0.05 & 0.05 & 0.05 \\
\hline \multirow{2}{*}{ Feb } & $1-15$ & 0.06 & 0.07 & 0.06 & 0.06 \\
\hline & $16-28$ & 0.09 & 0.09 & 0.09 & 0.09 \\
\hline \multirow{2}{*}{ Mar } & $1-15$ & 0.11 & 0.11 & 0.09 & 0.09 \\
\hline & $16-31$ & 0.15 & 0.14 & 0.14 & 0.12 \\
\hline \multirow{2}{*}{ Apr } & $1-15$ & 0.20 & 0.17 & 0.18 & 0.16 \\
\hline & 16-30 & 0.22 & 0.19 & 0.28 & 0.17 \\
\hline \multirow{2}{*}{ May } & $1-15$ & 0.23 & 0.22 & 0.23 & 0.21 \\
\hline & 16-31 & 0.27 & 0.23 & 0.24 & 0.22 \\
\hline \multirow{2}{*}{ Jun } & $1-15$ & 0.29 & 0.26 & 0.28 & 0.25 \\
\hline & $16-30$ & 0.30 & 0.27 & 0.29 & 0.26 \\
\hline \multirow{2}{*}{ Jul } & $1-15$ & 0.30 & 0.27 & 0.29 & 0.27 \\
\hline & 16-31 & 0.28 & 0.25 & 0.27 & 0.25 \\
\hline \multirow{2}{*}{ Aug } & $1-15$ & 0.28 & 0.24 & 0.26 & 0.24 \\
\hline & 16-31 & 0.25 & 0.22 & 0.24 & 0.21 \\
\hline \multirow{2}{*}{ Sep } & $1-15$ & 0.23 & 0.19 & 0.21 & 0.19 \\
\hline & 16-30 & 0.20 & 0.16 & 0.18 & 0.16 \\
\hline \multirow{2}{*}{ Oct } & $1-15$ & 0.17 & 0.13 & 0.16 & 0.14 \\
\hline & 16-31 & 0.13 & 0.10 & 0.12 & 0.10 \\
\hline \multirow{2}{*}{ Nov } & $1-15$ & 0.10 & 0.07 & 0.09 & 0.07 \\
\hline & 16-30 & 0.07 & 0.05 & 0.06 & 0.05 \\
\hline \multirow{2}{*}{ Dec } & $1-15$ & 0.05 & 0.04 & 0.05 & 0.04 \\
\hline & 16-31 & 0.03 & 0.04 & 0.04 & 0.03 \\
\hline
\end{tabular}

Table 4. Available crop coefficients for alfalfa

\begin{tabular}{|l|c|}
\hline Climatic condition & $\begin{array}{c}\text { Average crop } \\
\text { coefficient }\left(\mathbf{K}_{\mathbf{c}}\right)\end{array}$ \\
\hline Humid, light to moderate wind & 0.85 \\
\hline Dry with light to moderate wind & .95 \\
\hline Strong wind & 1.05 \\
\hline
\end{tabular}

Source: Doorenbos and Pruitt 1977. 
Table 5. Estimated water use (ETc) from historical ETo averages for Manteca (table 3) and the average crop coefficient (table 4)

\begin{tabular}{|c|c|c|c|c|c|}
\hline Period & Days & Daily $\mathrm{ET}_{0}$ & Period $\mathrm{ET}_{\mathrm{o}}$ & Crop coefficient, $\mathbf{K}_{\mathrm{c}}$ & Estimated $\mathrm{ET}_{\mathrm{c}}$ (in) \\
\hline $1 \mathrm{Apr}-15 \mathrm{Apr}$ & 15 & 0.17 & 2.55 & 0.95 & 2.4 \\
\hline $16 \mathrm{Apr}-30 \mathrm{Apr}$ & 15 & 0.19 & 2.85 & 0.95 & 2.7 \\
\hline 1 May - 15 May & 15 & 0.22 & 3.3 & 0.95 & 3.1 \\
\hline 16 May - 31 May & 16 & 0.23 & 3.68 & 0.95 & 3.5 \\
\hline 1 Jun - 15 Jun & 15 & 0.26 & 3.9 & 0.95 & 3.7 \\
\hline 16 Jun - 30 Jun & 15 & 0.27 & 4.05 & 0.95 & 3.8 \\
\hline $1 \mathrm{Jul}-15 \mathrm{Jul}$ & 15 & 0.27 & 4.05 & 0.95 & 3.8 \\
\hline $16 \mathrm{Jul}-31 \mathrm{Jul}$ & 16 & 0.25 & 4 & 0.95 & 3.8 \\
\hline 1 Aug - 15 Aug & 15 & 0.24 & 3.6 & 0.95 & 3.4 \\
\hline 16 Aug - 31 Aug & 16 & 0.22 & 3.52 & 0.95 & 3.3 \\
\hline $1 \mathrm{Sep}-15 \mathrm{Sep}$ & 15 & 0.19 & 2.85 & 0.95 & 2.7 \\
\hline 16 Sep - 30 Sep & 15 & 0.16 & 2.4 & 0.95 & 2.3 \\
\hline $1 \mathrm{Oct}-15 \mathrm{Oct}$ & 15 & 0.13 & 1.95 & 0.95 & 1.9 \\
\hline \multirow[t]{2}{*}{$16 \mathrm{Oct}-31 \mathrm{Oct}$} & 16 & 0.1 & 1.6 & 0.95 & 1.5 \\
\hline & & & & Total & 42.1 \\
\hline
\end{tabular}

irrigations is influenced by harvest practices. Harvest occurs about every 28 to 30 days, and irrigations must be timed around harvest events. Irrigation must occur long enough before a cutting to allow equipment on the field and keep the soil dry enough for hay to cure. The field cannot be irrigated again until the hay is cut and cured and the forage has been removed. Therefore, depending on the root zone, water-holding capacity of the soil, and the time of the year, growers must select the number of irrigations between harvests. To calculate the amount of water available to the crop, multiply the available soil moisture per foot (table 6) by the root zone depth. To prevent water stress, irrigation should occur when about $50 \%$ of the calculated water holding capacity of the root zone has been depleted. An example for a 4 -foot root zone on a loam soil would be

$1.8 \mathrm{in} / \mathrm{ft} \times 4 \mathrm{ft}$ rooting depth $=6.8$ in of available water 6.8 in $\times 0.5($ or $50 \%)=3.6$ in.
In this example, two irrigations per cutting would be adequate for most of the season. In areas with shallow groundwater a significant portion of the water needs of the crop may be supplied thereby reducing the irrigation requirement accordingly.

\section{Determining the irrigation amount}

Once the crop water requirement has been determined, the irrigator must account for losses such as evaporation, runoff, deep percolation, and the lack of irrigation uniformity. These losses depend on the irrigation system type and management. Border check irrigation can have substantial runoff losses and has larger variability in infiltration than do pressurized systems. This variability in infiltration requires that additional water be applied to deliver a minimum amount of water to all parts of the field. Compared with border check irrigation, sprinkler systems have greater application uniformity, less deep percolative losses, and little if any runoff. Drip systems have all the advantages of sprinkler systems, along with greater distribution uniformity and less evaporative loss.

To account for these losses and differences between irrigation systems, we calculate the irrigation efficiency to adjust the net irrigation water amount to meet the water requirement of the crop. Irrigation efficiency is the amount of water stored in the root zone and beneficially used by the crop divided by the amount of water applied. To adjust the net irrigation amount for system efficiency and to ensure that even the driest parts of the field receive the
Table 6. Available soil moisture for various soil textures

\begin{tabular}{|l|l|}
\hline Soil texture & $\begin{array}{l}\text { Available soil } \\
\text { moisture (in/ft) }\end{array}$ \\
\hline sand & 0.7 \\
\hline loamy sand & 1.1 \\
\hline sandy loam & 1.4 \\
\hline loam & 1.8 \\
\hline silt loam & 1.8 \\
\hline sandy clay loam & 1.3 \\
\hline sandy clay & 1.6 \\
\hline clay loam & 1.7 \\
\hline silty clay loam & 1.9 \\
\hline silty clay & 2.4 \\
\hline clay & 2.2 \\
\hline peat and muck & $2.5-3.5$ \\
\hline
\end{tabular}


net irrigation amount, divide it by the system application efficiency factor (table 7).

\section{Determining the irrigation application time}

The irrigation application time, or duration, for a surface irrigation system is determined by dividing the amount of water applied by the flow rate:

$$
T=A \times D \div Q,
$$

where $T=$ time required to irrigate the field (hours), $A=$ acres irrigated, $D=$ depth of applied water (inches), and $Q=$ flow rate into the field (cfs; $1 \mathrm{cfs}=449$ gallons per minute, or gpm).

Using our example of 4.8 inches and a 40 -acre field with a water supply of 2,000 gpm, the irrigation time would be

$$
\begin{aligned}
T=40 \mathrm{ac} & \times 4.8 \mathrm{in} \div 4.45 \mathrm{cfs} \\
= & 43 \mathrm{hr} .
\end{aligned}
$$

To irrigate four 2-acre checks,

$$
\begin{aligned}
T=8 \mathrm{ac} & \times 4.8 \mathrm{in} \div 4.45 \mathrm{cfs} \\
= & 8.6 \mathrm{hr} .
\end{aligned}
$$

Once the irrigation amount and timing of irrigation have been calculated, consider how conditions at the site may affect the application. For example, when using surface irrigation on high-infiltration soils, it may be difficult to apply the relatively small amount of water (as in our example) due to the large volume required to move water down the checks and the time required to advance the water to the end of the field: the excess infiltrated water would percolate below the root zone. The selection of appropriate flow volumes and cutoff times discussed below can minimize overapplication of water.

To determine the irrigation time for wheel-line and handmove sprinklers,

$$
T=D \div A R \text {, }
$$

where $T=$ time of irrigation (hours), $D=$ depth of applied water (inches), and $A R=$ application rate (inches/hour).
Using our example, 3.3 inches net irrigation requirement at an $80 \%$ irrigation efficiency equals a 4.4 inch gross irrigation application. For a sprinkler system with an application rate of 0.2 inches per hour the system application time would be

$$
\begin{gathered}
T=4.1 \mathrm{in} \div 0.2 \mathrm{in} / \mathrm{hr} \\
=20.5 \mathrm{hr}
\end{gathered}
$$

Table 7. Practical potential irrigation efficiencies of irrigation systems

\begin{tabular}{|l|l|}
\hline System type & Estimated efficiency, \% \\
\hline Surface irrigation & \\
\hline Border check* & $70-80$ \\
\hline Sprinkler & \\
\hline Continuous move & $80-90$ \\
\hline Periodic move & $70-90$ \\
\hline Portable solid set & $70-80$ \\
\hline
\end{tabular}

Source: Hanson 1995.

Note: *Efficiency reflects the use of a tailwater capture and return system.

If not available reduce by $15 \%$.

\section{Verifying calculations and applications}

The climate-based method described above for determining crop water gives an estimate of demand that should be verified and finetuned by soil-based monitoring of actual soil water status. Many devices can monitor soil moisture content and soil tension (see Schwankl and Prichard 2009). If the soil water content decreases or the soil water tension increases over the season, too little irrigation is being applied. If the soil water content increases or the tension decreases after each irrigation, too much water is being applied.

Modifying irrigation systems and management to reduce runoff As a general rule, the depth of water applied should match the amount of water used by the crop since the last irrigation, which is roughly equivalent to evapotranspiration (ET) (see "Irrigation Scheduling to Meet Crop Requirements," above). Additional water should be applied because no irrigation system is $100 \%$ efficient. 


\section{Modifying border check irrigation systems}

Irrigation runoff that enters surface waters can carry both dissolved and sediment-adsorbed pesticide residues. Soluble residue concentrations in runoff waters are fairly consistent for the entire runoff period. Therefore, any reduction in the total runoff volume will reduce the amount of residues. The degree to which soils erode during irrigation depends on a number of factors, with soil aggregate stability (the ability of soil particles to cling together and resist the forces of flowing water) being the most important.
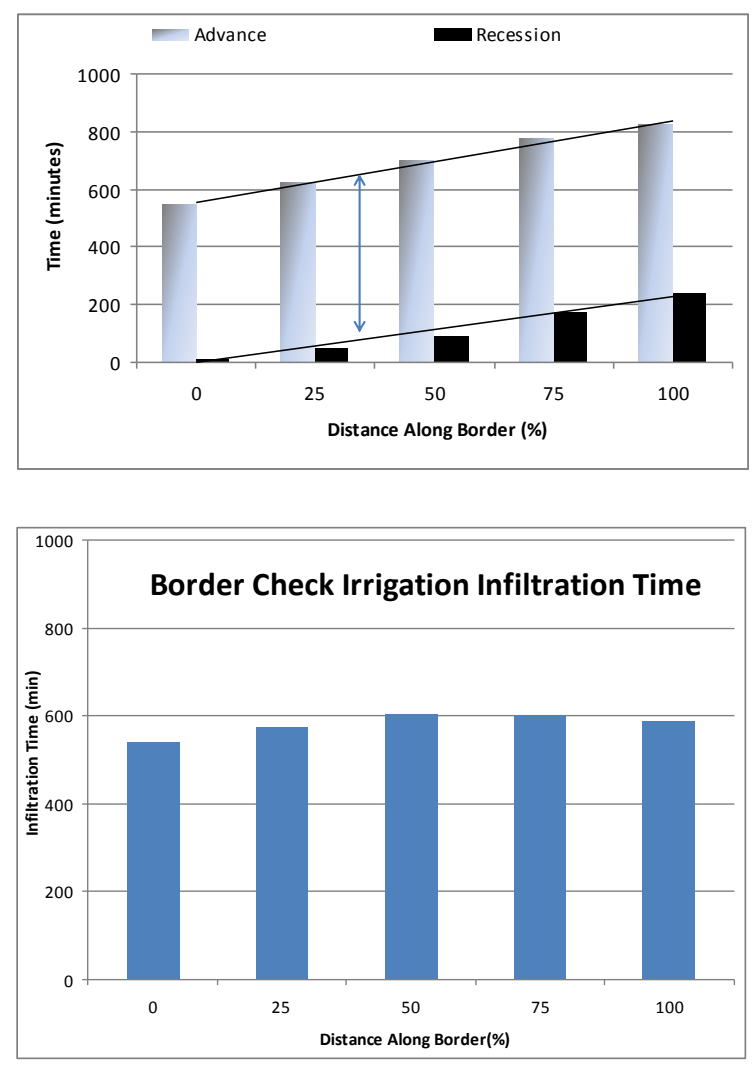

Figure 6. Border-check irrigation advance/ recession and infiltration time as a percentage of the field length. Source: Hanson and Schwankl 1995.
Aggregate stability can be enhanced by chemical and physical amendments and management practices discussed in the section "Improving Water Infiltration to Reduce Runoff," below Soil erosion rates depend on the soil conditions, including the amount, size, and density of loose particles on the soil surface. The amount of soil erosion depends on the velocity of the water and the duration of runoff. Therefore, reducing the peak volume and duration of runoff will reduce sediment loss. Generally, in border checks with alfalfa stems and litter, the water velocity is too low to cause erosion. However, when the water enters areas of little plant cover or into graded ditch areas, the increased velocity increases the potential for erosion.

Adjust the irrigation inflow rate and select an irrigation cutoff time to balance distribution uniformity and runoff volume. Higher flow rates in the check reduce the advance time but can increase runoff volume. Irrigation continues after the cutoff time until the water stored in the surface of the check is infiltrated or has run off.

The cutoff time for a given field depends on the time needed to infiltrate sufficient water along the lower part of the field. It may need to be determined on a trial-and-error basis. Figure $6 \mathrm{~A}$ illustrates a measured advance and recession in a border checkirrigated field Note that the advance and recession times are nearly linear and are parallel to each other. This pattern indicates a uniform infiltration opportunity as a result of the correct inflow rate and proper cutoff time. A shorter cutoff time would have reduced runoff volume but also reduced the distribution uniformity across the field. The goal is to achieve reasonable distribution uniformity and minimize runoff.

\section{Modifying pressurized irrigation systems}

Pressurized systems should be operated to meet the crop water requirement while eliminating surface runoff. Uniformity is designed into pressurized irrigation systems, with management left to ensure efficiency and the elimination of runoff losses by turning off the system before runoff occurs. The primary factor affecting uniformity is the pressure differential between sprinkler nozzles within the area irrigated. Pressure losses within the system can be a result of poor design, nozzle wear, and field elevation differences. If runoff occurs before the necessary water is infiltrated, the frequency of irrigation can be increased or the application rate can be decreased. Decreasing the application rate will require increasing the duration or perhaps the frequency to apply the desired amount of water.

\section{Improving Water Infiltration to Reduce Runoff}

Poor water infiltration can increase runoff from irrigation or winter rains. Irrigation runoff is typically associated with surface irrigation, but it can occur with pressurized systems on soils with poor infiltration or sloping land.

The first step in determining how to mitigate poor water infiltration is to understand the soil and water factors that influence 
it. At the onset of irrigation, water infiltrates at a high rate. Initially, the soil is dry and may have cracks through which water can infiltrate rapidly. After the soil near the surface wets for a few hours, the clay particles swell, closing cracks and limiting access to soil pores, which decreases infiltration rates. As wetting continues, the salinity and salt composition of the soil-water (water contained between soil particles) begins to more closely reflect that of the irrigation water, which is generally less saline. This reduction in soil water salinity retards water infiltration.

Water infiltration can be improved by increasing the soil total pore volume or individual pore size and by providing better access to surface pores. Physical practices that disrupt the soil and applying chemical and organic amendments are attempts to influence these factors. For an in-depth analysis of water infiltration problems and solutions see Singer et al. 1992.

\section{Impact of soil structure on water infiltration}

Pores are the spaces between mineral and organic particles in soils through which water and air move. Soils with a predominance of sand (larger, spherical particles) tend to have larger pores, while soils with a predominance of clay (plate-like particles) tend to have smaller pores. With some exceptions, soils with larger pores generally have higher infiltration rates. Water usually moves more slowly through small-pored soils because the smaller pores provide more surface area for water to adhere to. On the other hand, clay soils that form cracks as the soil dries and shrinks can have higher water infiltration rates, at least initially.

Individual soil particles can clump together, forming larger structures called aggregates. The small pores between particles remain, and larger pores formed between the aggregates significantly enhance water infiltration and gas exchange (fig. 7). Soil water salinity and individual mineral constituents, as well as organic matter content, play a significant role in stabilizing soil aggregates and increasing pore size.

Soil crusts, or surface seals, reduce infiltration by impeding water access to soil pores beneath the crust layer. Crusts form at the soil surface when the soil aggregates become dispersed, causing a loss of porosity. Weak cementation of the crust often follows when the soil dries, slowing water penetration during succeeding irrigations. In fine-textured silty soils, soil crusts are often caused by excess exchangeable sodium in the soil or irrigation water, or too little total salinity. In coarse- to medium-textured nonsaline and nonsodic soils, continued cultivation can reduce pore size and number to the point where water infiltration is reduced. This problem can be made worse if the irrigation water has very low salinity, such as water from irrigation districts on the east side of the San Joaquin Valley. Additionally, wells that contain a high level of bicarbonate and a relatively low level of calcium encourage crusting.

\section{Irrigation water quality}

Irrigation water quality (salinity and sodicity) influences water infiltration rates by affecting whether soil particles tend to absorb water, stay together, or become separated by swelling. The swelling of soil particles causes aggregate breakdown and soil particle dispersion, resulting in the formation of surface crust.
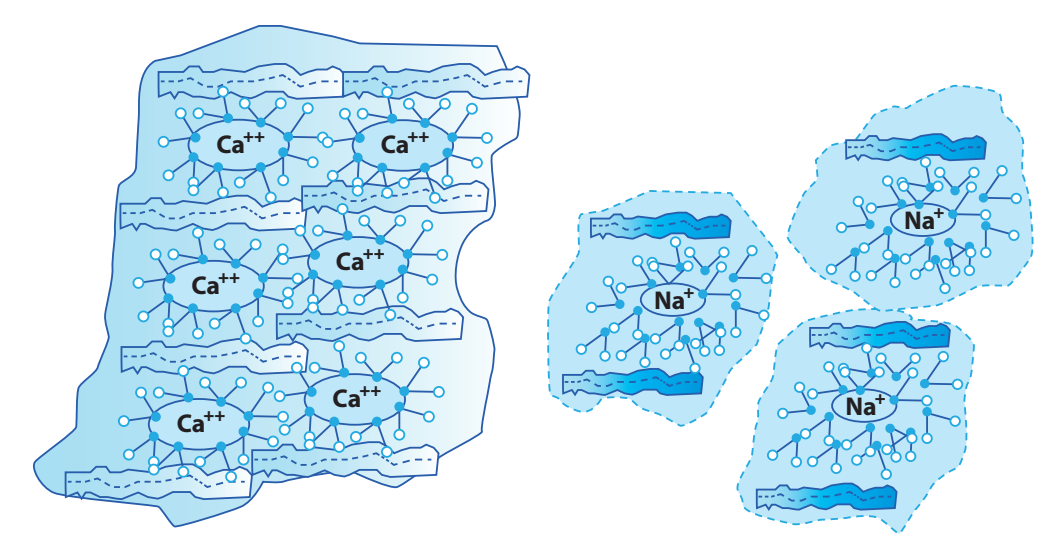

Figure 7. Soil aggregate stability: forming stable aggregates with plentiful calcium on clay exchange sites (left), compared with weak soil aggregates due to low salinity and/or excessive sodium in the soil pore water (left). 


\section{Salinity}

The higher the salinity of the irrigation water, the more likely that aggregates will remain stable, preserving infiltration rates. Salinity is measured by determining the electrical conductivity (EC) of the irrigation water $\left(\mathrm{EC}_{\mathrm{w}}\right)$ or soil water extracted from a saturated soil paste $\left(\mathrm{EC}_{\mathrm{e}}\right)$.

\section{Sodicity}

The index for sodicity is the sodium adsorption ratio (SAR), which depends on the relative amounts of sodium, calcium, and magnesium in the irrigation water. The SAR of a soil sample can also be used to estimate exchangeable sodium levels in the soil. With increasing levels of exchangeable sodium, the affinity of soil particles for water increases and aggregate stability decreases, reducing water infiltration rates.

\section{Combined effect of salinity and sodicity}

Since both the salinity and sodicity of irrigation water affect aggregate stability and water infiltration, both must be assessed when diagnosing poor infiltration. In the top 3 inches of soil, the salinity and sodicity of the irrigation water and soil are closely linked. Consequently, samples of surface soil and irrigation water must be tested to diagnose the problem and evaluate the likelihood of success of mediation practices. In general, aggregate stability and infiltration rates increase as EC increases and the SAR decreases

Table 8. Potential for a water infiltration problem

\begin{tabular}{|l|l|l|}
\hline SAR $^{*}$ & $\begin{array}{l}\text { Problem likely } \\
\mathrm{EC}_{\mathrm{e}}^{\dagger} \text { or } \mathrm{EC}_{\mathbf{w}}{ }^{\ddagger} \\
\mathbf{d S} / \mathbf{m}\end{array}$ & $\begin{array}{l}\text { Problem } \\
\text { unlikely } \\
\mathrm{ECe} \text { or ECw } \\
\mathbf{d S} / \mathbf{m}\end{array}$ \\
\hline $0.0-3.0$ & $<0.3$ & $>0.7$ \\
\hline $3.1-6.0$ & $<0.4$ & $>1.0$ \\
\hline $6.1-12.0$ & $<0.5$ & $>2.0$ \\
\hline
\end{tabular}

Source: Ayers and Westcot 1985.

Notes:

*Sodium adsorption ratio.

tElectrical conductivity of a soil saturated paste.

*Electrical conductivity of irrigation water. (table 8). As a general guideline, the SAR should be less than 5 times the EC (fig. 8). The exception is low-salt water with EC values of less than $0.5 \mathrm{dS} / \mathrm{m}$, which is corrosive and depletes surface soils of readily soluble minerals and all soluble salts. It often has a strong tendency to dissolve all sources of calcium rapidly from surface soils. The soils then break down, disperse, and seal, resulting in poor water infiltration.

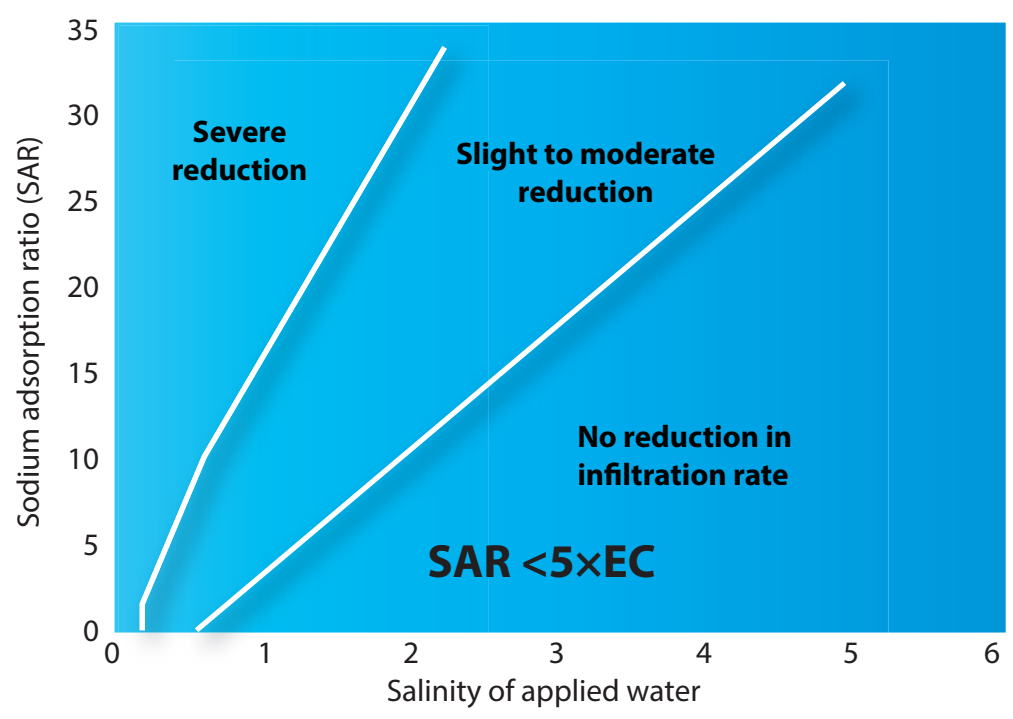

Figure 8. Interaction of total salinity as $\mathrm{EC}_{\mathrm{w}}$ with the sodium adsorption ratio (SAR) of irrigation water for causing potential infiltration problems.

The guidelines based on EC and SAR discussed above may not work for all California soils. Some soils contain a large amount of serpentine clays rich in magnesium $(\mathrm{Mg})$ and low in calcium (Ca). In these soils, magnesium may have the same soil-dispersing effect as sodium. Soils with a predominance of montmorillonite and illite clays are also easily dispersed by excess magnesium. Although the diagnostic criteria for such conditions have not been extensively tested, some studies suggest that when the magnesium to calcium ratio of these soils exceeds 1:1, they may be prone to poor water infiltration. Some studies report that high levels of soil potassium can also promote aggregate dispersion and soil crusting.

High levels of carbonate $\left(\mathrm{CO}_{3}^{-}\right)$and bicarbonate $\left(\mathrm{HCO}_{3}{ }^{-}\right)$in water increase the sodium hazard of the water to a level greater than that indicated by the SAR. In alkaline soils, high levels of carbonate 
and bicarbonate tend to precipitate calcium carbonate (lime, $\left.\mathrm{CaCO}_{3}\right)$ and magnesium carbonate $\left(\mathrm{MgCO}_{3}\right)$ when the soil solution becomes concentrated during soil drying. The concentrations of calcium and magnesium in the soil solution are reduced relative to sodium, and the SAR of the soil solution tends to increase.

An adjusted SAR value may be calculated for water high in carbonate and bicarbonate if the soil being irrigated contains free lime (calcareous soil). The adjusted SAR and knowledge of soil properties help determine management practices when using highbicarbonate water.

\section{Mitigating poor water infiltration}

Solving poor infiltration by modifying irrigation practices, as discussed in other sections of this publication, should always be the starting point and will generally be less costly than the soil and water modifying treatments discussed below. Poor water infiltration that is not amenable to improvement by optimizing irrigation system design and operation may be mitigated by improved management of soil organic matter or by soil tillage or by using chemical amendments.

\section{Soil organic matter}

Soil organic matter helps stabilize soil aggregates by increasing the number of exchange sites in the soil matrix and encouraging microbial activity. Soil microbes that decompose soil organic matter produce polysaccharides and polyuronides, which act as binders to stabilize aggregates, improving porosity and water infiltration. Over time, continued cultivation reduces the organic matter content and aggregate stability of soils. These changes can reduce water infiltration and increase the runoff potential.

In most of California, it is difficult to increase and sustain soil organic matter under the prevailing warm, semiarid conditions that favor rapid organic matter decomposition. Adding organic matter to improve or sustain aggregate stability and water infiltration must be incremental and continual to be effective. Growers can achieve this in the following ways.

\section{Crop residues}

An alfalfa crop already has a fair amount of plant matter that makes its way to the soil surface. However the residues of rotation crops offer a much greater opportunity to add significant amounts of organic matter. Field crop residues, whether shredded or soil incorporated, can be left to decompose adding organic matter (and some nutrients) to the soil. Crop residue biomass in California's Central Valley ranged from 9,560 pounds per acre for corn after grain harvest to 570 pounds per acre for onions; for tomato, the average was 2,880 pounds per acre. Wheat biomass was 4,800 pounds per acre after grain harvest, but after baling, only 670 pounds remained (Mitchell et al. 1999).

\section{Manure and other organic materials}

With proper handing and management to avoid risk of crop contamination by human pathogens, animal manures or compost can help increase soil organic matter content and improve water infiltration. However, the application of manures is currently uncommon due to the limited availability of manures.

\section{Chemical amendments}

Adding chemical amendments to water or soil can improve water infiltration by increasing the total salt concentration or decreasing the sodium adsorption ratio (SAR) of the soil-water. These actions enhance aggregate stability and reduce soil crusting and pore blockage. Four types of materials are used to ameliorate water infiltration: salts, as fertilizers; calcium materials; acids or acidforming materials; and soil conditioners, including polymers and surfactants.

Salts. Any fertilizer salt or amendment that contains salts, when applied to the soil surface or dissolved in irrigation water, increases the salinity of the irrigation water and ultimately influences the soil-water. Whether increased salinity is advantageous depends on the SAR of the irrigation water. The largest effect of salt addition is in irrigation water that has very low salinity (EC less than $0.5 \mathrm{dS} / \mathrm{m}$ ). Increasing salinity to an EC above $4 \mathrm{dS} / \mathrm{m}$ has little effect on infiltration. 
Table 9. Amount of amendments required for calcareous soils to increase the calcium content in the irrigation water by $1 \mathrm{meq} / \mathrm{L}$

\begin{tabular}{|l|l|c|}
\hline Chemical name & Trade name and composition & $\begin{array}{c}\text { Amount of water to } \\
\text { obtain } \mathbf{1} \text { meq/L free } \\
\text { Ca* (lb/ac-ft_ }\end{array}$ \\
\hline sulfur & $\mathrm{S}, 100 \%$ & 43.6 \\
\hline gypsum & $\mathrm{CaSO}_{4} \cdot \mathrm{H}_{2} \mathrm{O}, 100 \%$ & 234 \\
\hline calcium polysulfide & Lime-sulfur, 23.3\% S & 191 \\
\hline calcium chloride & Electro-Cal, 13\% calcium & 418 \\
\hline potassium thiosulfate & $\mathrm{KTS}, 25 \% \mathrm{~K}_{2} \mathrm{O}, 26 \% \mathrm{~S}$ & 256 \\
\hline ammonium thiosulfate & Thio-sul, 12\% N, 26\% S & $110^{\dagger}$ \\
\hline ammonium polysulfide & Nitro-sul, 20\% N, 40\% S & $336^{\ddagger}$ \\
\hline $\begin{array}{l}\text { monocarbamide dihydrogen sulfate/ } \\
\text { sulfuric acid }\end{array}$ & $\mathrm{N}^{+}$-phuric, US-10; 10\% N, 18\% S & $69^{\dagger}$ \\
\hline sulfuric acid & $\mathrm{H}_{2} \mathrm{SO}_{4}, 100 \%$ & $136^{\ddagger}$ \\
\hline Notes: & $148^{\dagger}$ \\
\hline
\end{tabular}

Notes:

"Salts bound to the soil are replaced on an equal ionic charge basis and not equal weight basis.

${ }^{+}$Combined acidification potential from $\mathrm{S}$ and oxidation of $\mathrm{N}$ source to $\mathrm{NO}_{3}$ to release free Ca from soil lime. Requires moist, biologically active soil.

${ }^{\ddagger}$ Acidification potential from oxidation of $\mathrm{N}$ source to $\mathrm{NO}_{3}$ only.

Calcium materials. Adding calcium salts to soil and water increases the total salinity and soluble calcium. The calcium salt commonly used on alkaline (high-pH) soils is gypsum $\left(\mathrm{CaSO}_{4}\right)$, but calcium chloride $\left(\mathrm{CaCl}_{2}\right)$ and calcium nitrate $\left(\mathrm{CaNO}_{3}\right)$ are sometimes used. These are fairly soluble and can easily be applied though the irrigation water. Care should be taken if the water contains more than $2 \mathrm{meq} / \mathrm{L}$ of bicarbonate $\left(\mathrm{HCO}_{3}\right)$. Adding gypsum to such water through a drip system significantly increases the likelihood that lime precipitate will clog the system; if it does, application of acid to decrease bicarbonate concentrations may be necessary. Lime and dolomite are used only for broadcast applications on acid soil, as they are virtually insoluble under alkaline conditions.
Adding gypsum to irrigation water at rates that supply 1.0 to $3.0 \mathrm{meq} / \mathrm{L}$ of calcium is considered low to moderate; rates that supply 3.0 to $6.0 \mathrm{meq} / \mathrm{L}$ of calcium are considered moderate to high. The following sample calculations show how to estimate the quantity of gypsum required to improve infiltration. Table 9 lists the amount of gypsum and other products needed to increase the calcium content of irrigation water by $1 \mathrm{meq} / \mathrm{L}$ per acre-foot; applying 234 pounds of $100 \%$ pure gypsum per acre-foot of water provides $1 \mathrm{meq} / \mathrm{L}$ of free calcium. It is rarely necessary to inject gypsum constantly. Injection every other or every third irrigation may be all that is necessary to end the season with the required amount. Injecting gypsum in drip irrigation during the season is usually more beneficial than applying it to the surface during the fallow season.

An alternative to treating water with calcium materials is broadcasting amendments such as gypsum on the soil surface prior to planting. The primary advantage of this approach is that it is often less expensive than treating water. Surface applications are most effective when gypsum is applied at rates equivalent to 1 to 2 tons per acre prior to planting. When applied in the fall, higher rates must be used.

Acids and acid-forming materials. Commonly applied acid or acid-forming amendments include sulfuric acid $\left(\mathrm{H}_{2} \mathrm{SO}_{4}\right)$ products, soil sulfur, ammonium polysulfide, and calcium polysulfide. The acid from these materials dissolves soil-lime to form a calcium salt (gypsum), which dissolves in the irrigation water to provide exchangeable calcium. The acid materials react with soil-lime the instant they come in contact with the soil. Materials containing elemental sulfur or sulfides must undergo microbial degradation in order to produce acid. This process may take months or years, depending on the material and particle size (in the case of elemental sulfur). Since these materials form an acid via the soil reaction, they reduce soil $\mathrm{pH}$ if applied at sufficiently high rates.

Acids are applied to water for two purposes in relation to water infiltration problems. The first is to dissolve soil lime (the soil must contain lime if acids are used), which increases free calcium in the soil-water and improves infiltration. The second is to 
prevent lime clogging in drip systems when adding gypsum to water containing greater than $2 \mathrm{meq} / \mathrm{L}$ bicarbonate.

Table 9 indicates that it takes 133 pounds of $100 \%$ pure sulfuric acid per acre-foot of water to release $1 \mathrm{meq} / \mathrm{L}$ of calcium. This assumes that the acid contacts lime in the soil, neutralizing the carbonate molecule and releasing calcium. This is the same amount of acid required to neutralize $1 \mathrm{meq} / \mathrm{L}$ of bicarbonate in the water. If the water contains bicarbonate, the acid will neutralize it, converting it to carbon dioxide, which is released to the atmosphere. To dissolve lime in the soil, the level of acid applied must be greater than the level of bicarbonate in the water; if the level of acid is lower, the $\mathrm{pH}$ of the water will not decrease.

Soil conditioners. These primary soil condition amendments are surfactants and organic polymers. Although there is a long history of developing and testing other amendments, such as synthetic and natural soil enzymes and microbial soups, not enough data exists on them to conclude that they are uniformly effective. Surfactants, or wetting agents, reduce the surface tension of water; they are not effective in agricultural soils.

Organic polymers, mainly water-soluble polyacrylamides (PAM) and polysaccharides, stabilize aggregates at the soil surface. These extremely long-chain molecules wrap around and through soil particles to bind aggregates together. This action helps resist the disruptive forces of droplet impact and also helps decrease soil erosion and sediment load in furrow irrigation systems. Studies have shown that PAM can improve infiltration into soils with illite and kaolinitic clays common in the northwest United States (Sojka et al. 2007). Research conducted in California found that infiltration is not improved in soils with the mostly montmorillonite (swelling) clays typical of the San Joaquin Valley (Long et al. 2010a). PAM has limited applicability for improving infiltration rates in alfalfa. For more information on water infiltration, see Singer et al. 1972.

\section{Capturing and Filtering Surface Water and Sediments}

Reducing the volume or velocity of runoff water can reduce the offsite movement of residues, whether in solution or attached to sediment. The most common methods of capturing and filtering surface water and sediment are sediment basins growing vegetation at the tail of the field or in drainage ditches.

\section{Storing runoff}

Storage of runoff water from storm events in impoundments is often suggested as a mitigation practice for preventing offsite movement of chemicals. The sheer volume of runoff makes this a poor option. Storms are rated as to the frequency at which a particular amount of rainfall in a given duration is expected to return, on average. A 2-year, 24-hour storm would be the rainfall event one could expect during a 24-hour period on the average of every 2 years. For example, a 2-year, 24-hour storm in Stockton, California, is 1.6 inches. That amount of rainfall on a 40 -acre parcel would produce over 1,700,000 gallons, or 5.3 acre feet, of water, equivalent to a 1 -acre pond over 5 feet deep. A single hundred-year storm would require three times that volume. Of course, some of the water would infiltrate into the field. However, if one storm came on the heels of another, most of the rainfall would run off. For more information, see Schwankl et al. 2007a.

\section{Sediment basins}

A sediment basin or trap is located at the low elevation portion of the field with a overflow pipe or spillway. These basins can be designed by the Natural Resources Conservation Service (NRCS) or a civil engineer on a site-specific basis and should be installed using proper construction methods (fig. 9). Basins should be sized to retain the entire runoff volume. If the runoff volume is small, a basin effectively reduces offsite movement of sediment containing adsorbed pesticide residues. If runoff is high enough to cause low retention times, sediment removal efficiency declines rapidly.

\section{Effectiveness in removing pesticide residues}

Long et al. (2010b) found that retention times of 60 to 90 minutes in a sediment basin that was $1.4 \%$ of the irrigated area effectively removed particles coarser than fine silts. Finer soil particles, which generally adsorb pyrethroid pesticide residues, were not removed from the runoff. During the first irrigation of the season (soon after cultivation in a furrow-irrigated crop), $39 \%$ of the sediment load entering the pond was removed. In the second measured irrigation, 


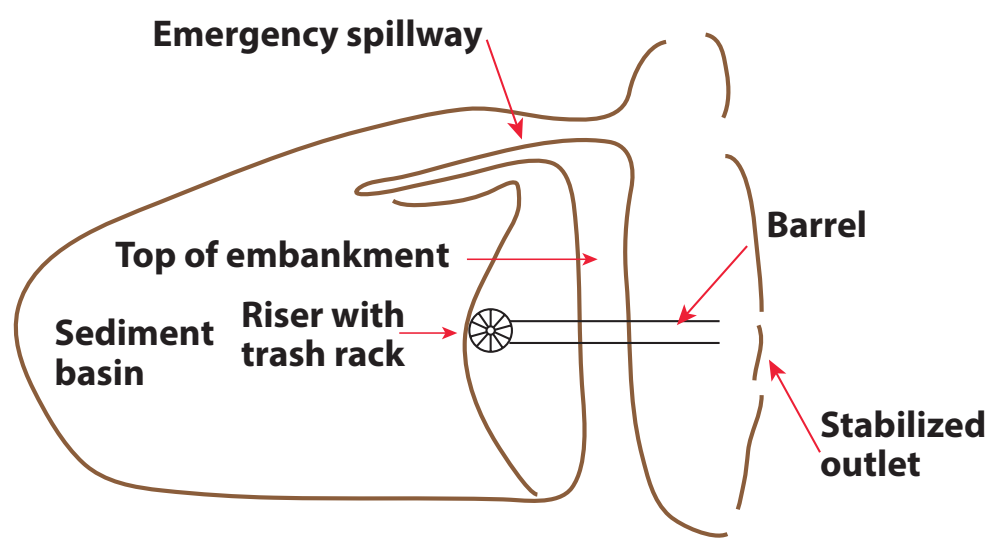

Figure 9 . Sediment basin with spillway and release structure.

sediment removal was insignificant. The effectiveness of sediment traps was found to be limited by the time available for suspended sediments to settle out of the runoff before discharge. Sediment basins may be ineffective with finer soils at higher runoff rates. Long (2010b) suggests settling basins of various size based on Stokes' Law. Clay particles carry the bulk of the adsorbed pesticide residues. A settling basin of 57 acre feet would be required to provide enough time to settle these small particles out of tailwater runoff at 50 gallons per minute.

A study was conducted in the Central Valley to measure pyrethroid removal by a tailwater recovery pond (Markle 2009). A pyrethroid, lambda-cyhalothrin, was applied to a border-checkirrigated almond orchard at the rate of 0.04 pounds of active ingredient per acre. Runoff water was measured for volume, sediment, and pyrethroid residue concentration as inflow and outflow in a recycling pond that was 19 feet by 16 feet by 7 feet deep. About $15 \%$ of the irrigation onflow water exited the field as runoff. The pond reduced the sediment in the water by $80 \%$ and pyrethroid residues by $61 \%$ (inflow to outflow). The difference in the removal efficiencies for sediment and pyrethroid residues was probably due to the adsorption of lambda-cyhalothrin residues to lighter-weight clay particles that did not have a chance to settle out in this trial. Removal efficiency may have been further improved with lower flow rates or longer retention times in the pond.

\section{Vegetative filter strips and drain ditches}

The tail end of an alfalfa field is often weak due to over- or underirrigation, resulting in plant losses. These weak areas often have high soil erosion due to the lack of vegetation holding the soil. To help stabilize the soil and prevent offsite movement of pesticides, the tail ends of fields can be overseeded with other forages, such as grasses or legumes, creating a vegetated filter strip. Suggested perennial forages that would work well as vegetative filter strips in alfalfa include orchardgrass, fescue, and red clover, as described in Canevari et al. 2000. These forages are best seeded during early fall after lightly harrowing the field to form a suitable seedbed. Grasses are a good fit for the horse hay market, while clovers are suitable for dairies. If the alfalfa stand will remain in production for less than a year, annual forages for overseeding in alfalfa include oats or berseem clover.

Drainage ditches can be vegetated with plant material that help capture sediments and other sediment-absorbed pollutants and also provide for some water infiltration (fig. 10). The common type of a vegetative drain ditch is a $V$-shaped ditch 2 to 3 feet deep and 4 feet wide at the top. Short, sturdy, hardy perennial grasses such as dwarf fescues and perennial ryegrass are preferred, since once established they withstand the force of runoff water and summer drought conditions. Vegetation in the ditch can also be resident, such as rushes and bermudagrass. Residue removal efficiency is strongly influenced by runoff flow rate per unit of ditch wetted area. Higher flow rates reduce the removal efficiency.

\section{Effectiveness in removing pesticide residues}

The chemical characteristics of a given pesticide determine the type and amount of residue reduction achievable with vegetative strips or ditches. Organophosphate pesticides tend to be water soluble, while pyrethroids are virtually insoluble in water and are primarily adsorbed to sediments. 


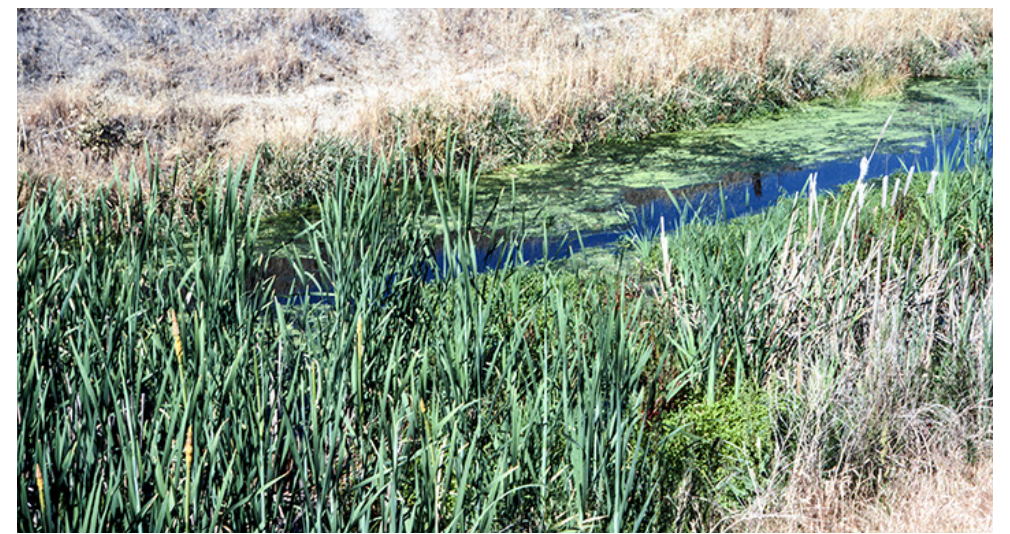

Figure 10. Vegetative drainage ditch. Photo courtesy UC ANR.

Diazinon, an organophosphate with high solubility in water, can be expected to remain in solution for long periods (Bondarenko and Gan 2004). Previous evaluations of the effectiveness of vegetation for removing diazinon from water have shown mixed results. Watanabe and Grismer (2001) evaluated diazinon removal by vegetative filter strips under controlled laboratory conditions and found that the majority of diazinon removal occurred via infiltration into the root zone and adsorption to vegetative matter. However, $73 \%$ of the applied diazinon was detected in the runoff water leaving the vegetative strip. Long et al. (2010b) found that reduction in sediment load was directly related to pyrethroid residue removal by the filter strip. Sediment runoff was reduced by $62 \%$ when furrow runoff water passed through a well-established vegetative strip planted to either tall fescue or a perennial ryegrass and tall fescue mixture that represented $2.8 \%$ of the field being irrigated. They recommend 0.03 acres of vegetative filter per 100 gallons per minute of tailwater to significantly improve the water quality of field runoff. It should be noted that a vegetative filter strip is used once per irrigation, not for successive sets as would a vegetative ditch. Anderson et al. (2008) found that a vegetative ditch containing aquatic vegetation removed only $4 \%$ of diazinon in contaminated runoff. Moore et al. (2008) used a simulated runoff event to evaluate removal of diazinon in vegetative ditches in Yolo
County, California. They described reductions in diazinon runoff using a V-shaped vegetative ditch, but significant concentrations of diazinon remained in the system outflow after five hours. Essentially, diazinon levels were not reduced in runoff water that did not infiltrate into the root zone of the ditch

Chlorpyrifos, another organophosphate, is more hydrophobic than diazinon. Gill et al. (2008) applied chlorpyrifos at 1 pint per acre and found a $40 \%$ reduction in the water column concentration after passage through a vegetative ditch, though the residue concentration in the outflow water was still 33 times over the water quality standard of 15 parts per trillion (ppt). Anderson et al. (2008) found an average 35\% reduction in chlorpyrifos concentration in two evaluations after passage through a vegetative ditch containing aquatic vegetation. On the other end of the spectrum, Cole et al. (1997) found vegetative filter strips to be effective in reducing 62 to $99 \%$ of chlorpyrifos residues in runoff water. Local conditions, including runoff flow rates, size of the vegetative area, and the initial residue concentration, appear to have strongly influenced the effectiveness of these studies. Because of their hydrophobic nature, pyrethroids adsorb readily to plant surfaces and soil particles and are therefore easier to remove from runoff water than are organophosphates(Moore et al. 2001; Schulz 2004). Moore et al. (2008), for example, found that vegetation was much more effective at removing the pyrethroid pesticide permethrin than the organophosphate diazinon. Anderson et al. (2008) found nearly $100 \%$ reduction of permethrin after treatment in a vegetative ditch. Additionally, Gill et al. (2008) found a $25 \%$ reduction in pyrethroid (lambda-cyhalothrin) residues after moving runoff water through a vegetative ditch.

\section{Tailwater Collection and Recycling}

Tailwater (runoff from the end of a field) is most often associated with surface irrigation (furrow and border-check systems), since well-designed sprinkler and drip irrigation systems should not produce tailwater runoff. Tailwater collection and recycling is an excellent management practice for improving irrigation efficiency and minimizing tailwater impacts. 
If a new tailwater return system is being planned, management is a key factor in its design. Tailwater generated by irrigation practices is usually pumped from the capture pond through a pipeline to where it will be reapplied. Such a system, when well operated, maximizes irrigation efficiency and minimizes environmental impacts.

\section{Advantages and disadvantages of a tailwater return system}

\section{Advantages}

- Minimizes offsite environmental impacts of tailwater potentially containing pesticide and fertilizer residues.

- Improves irrigation efficiency since tailwater is reused as irrigation water.

- May reduce water costs.

- Removes standing water that can cause crop loss and weed infestations.

\section{Disadvantages}

- Can be expensive to install, maintain, and operate (NRCS cost sharing programs are available in many areas).

- Takes land out of production for the pond and other tailwater recovery system components.

- Requires careful management and timely recycling of tailwater pond contents.

\section{Tailwater return system management}

There are numerous ways of managing tailwater return systems, and their management is often constrained by the system design. See Schwankl et al. 2007 for information on design, construction, costs, and operation; see NRCS 2007 for further information on design and operational standards.

\section{Treatment of Runoff Water}

Runoff water can be chemically treated to reduce pesticide residues. This treatment can be done in the tailwater ditch or in a holding basin. Two products have been shown to be effective for this purpose: polyacrylamide (PAM) for reducing pyrethroid-laden sediments and Landguard OP-A Enzyme for treatment of runoff water containing soluble organophosphate pesticides. Work is underway to develop enzymes to treat pyrethroid residues.

\section{Polyacrylamide (PAM)}

PAM is effectively reduces pesticide residues attached to soil particles (generally, pyrethroids) that leave the field or are generated in a tailwater ditch through erosion during irrigation. Studies have shown that for other crops this erosion occurs along the field length during furrow irrigation. However, for alfalfa, little or no soil erosion occurs as water advances down the field. Suspended solids in the irrigation water are filtered out as the water flows across the field because of the filtering effect of the alfalfa and the residual organic matter on the soil surface. Observations made during alfalfa irrigations found that erosion occurs at the end of the field mainly due to the surface runoff flowing into and down the tailwater ditch. Some erosion also occurs during the last 15 to 20 feet of the field, where bare soil usually exists in alfalfa fields. In one study, suspended solids were measured in source and tail waters during alfalfa border check irrigation at fifteen sites (Long et al. 2002). Tailwater was not found to be significantly degraded by sediment. PAM is a solid or liquid water-soluble polymer that flocculates sediments, binding them together and causing them to drop out of the water. When added to runoff water, PAM can mitigate transport of sediment-adsorbed pesticides from irrigated fields. Liquid PAM can be constantly injected into the tailwater ditch or deposited in granular form into turbulent water in the tailwater ditch, where it is slowly dissolved by irrigation water. PAM is more effective in finetextured soils and in irrigation water that contains calcium and little sodium.

\section{Effectiveness in removing pesticide residues}

PAM has been shown to be effective in reducing sediments when applied in irrigation furrows (Sojka et al. 2007; Trout et al. 1995; Long et al. 2010b). Although these results are based on furrow or head ditch applications, results are mixed as to the effectiveness of PAM applied to tailwater to control sediment loss. Poor results have been reported when applying PAM into the tailwater ditch with 
a high runoff water velocity and quick discharge time. Favorable results were obtained when applied to the ditch combined with short-term sediment basin use before discharge.

\section{Landguard OP-A degradation enzyme}

Runoff water containing organophosphate insecticide residues can be treated with Landguard OP-A, a degradation enzyme, to reduce or eliminate residues in runoff water before it exits the farm. This product promotes the breakdown of most organophosphate pesticides into less-toxic metabolites. The powdery enzyme is mixed with water into a stock solution and usually applied to runoff water in the tailwater ditch, but it can also be applied to a holding basin. The enzyme treatment rate, residue concentration, and time available before runoff discharge must be carefully managed to ensure degradation at a minimum material cost. Increasing the time between treatment and runoff discharge allows for a lower enzyme application rate.

The key factor in determining the correct application rate is the maximum expected runoff rate. The runoff rate is typically not constant over time. When using a single application rate based on the maximum estimated flow rate, overapplication is likely at the lower flows that typically occur at the beginning and end of runoff. Additionally, the practice of irrigating more checks during a nighttime set can lead to different peak flows of different duration.

A comparison was made of the amount of enzyme required for single maximum-rate application for an entire runoff period and for a variable rate as required by the flow rate, essentially keeping the application rate constant (Prichard and Antinetti 2009). A single rate for the maximum volume during the first irrigation resulted in an application rate that was more than double the amount needed. Estimating that the next set would have nearly the same runoff flow rate and using the same application rate, the second set required over 6 times the rate of a correctly managed variable system due to the lower amount of runoff.

Effectiveness in removing pesticide residues

A field trial in California found chlorpyrifos in runoff at a concentration near $10 \mathrm{ppb}$ prior to Landguard OP-A treatment;
12 minutes after the enzyme was added at a rate of 4.3 ounces per acre-foot of runoff water, the chlorpyrifos concentration declined to $0.4 \mathrm{ppb}$ (Weston and Jackson 2010). At higher rates, chlorpyrifos became undetectable. The effects of the enzyme on chlorpyrifosrelated toxicity are equally dramatic. The enzyme reduces chlorpyrifos toxicity to Hyalella azteca (a test organism) by at least 70-fold compared with untreated water. Without the enzyme, the concentration of chlorpyrifos required to kill half the test organisms was $141 \mathrm{ppb}$; with enzyme, none of the test organisms were killed.

A team led by Brian Anderson of the UC Davis Marine Pollution Studies Laboratory applied Landguard OP-A at the rate of 4.3 ounces per acre-foot of runoff water directly into a drainage ditch containing diazinon residues (Anderson et al. 2008). Samples of runoff water were collected from the ditch before application and 107 feet downstream from the electronic application unit (fig. 11). In multiple trials, Anderson found that samples treated with Landguard OP-A removed all detectable diazinon, and all were nontoxic to Ceriodaphnia dubia, another aquatic arthropod test organism.

\section{A Risk Analysis Case Study}

The management practices presented in this publication have been proven to effectively reduce the offsite movement of pesticide residue in runoff from alfalfa field operations. The following case study expands on the example introduced in the "Overview of Risk Evaluation," above, and illustrates how specific changes can be made in field operations to reduce pesticide movement from the field. For further information on management options given below, see the discussions in earlier sections of this publication.

Crop: Alfalfa, 40 acres.

Topography: $0.15 \%$ slope.

Soil: Hollenbeck silty clay loam soil, which tends to crust, limiting the water infiltration rate.

Irrigation system: Border-check irrigation, checks 53 feet wide.

Irrigation Runoff: About $17 \%$ of the applied water.

Irrigation water: $\mathrm{pH} 7.5, \mathrm{EC} 0.2 \mathrm{dS} / \mathrm{m}$. 


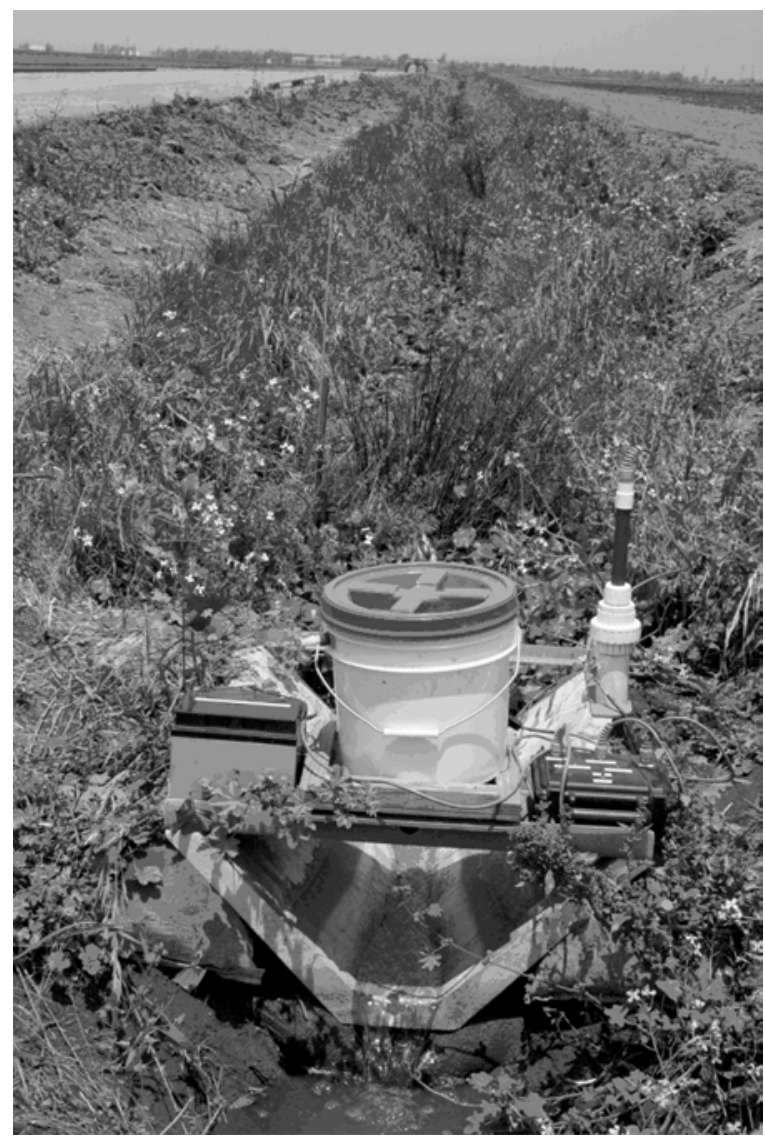

Figure 11 . Anderson trial showing vegetated ditch and electronic dosing unit, 2008. Photo: B. Anderson.
Drainage: Runoff moves to a

drainage ditch at the end of the field, then enters a larger creek.

Pesticide mixing and loading: A pesticide mixing and loading area is located 40 feet from the drainage ditch.

Pest: Egyptian alfalfa weevil, 20 per sweep.

We begin the risk assessment with Flowchart 1 (FC1), considering possible routes by which pesticide could move off the field and the operations or conditions that may contribute to or mitigate the risk. We will determine whether a risk exists for irrigation runoff, stormwater runoff, and spray drift, then review management practices to mitigate the risk.

\section{Irrigation Runoff Risk}

We begin the risk assessment with Flowchart 1 to evaluate risks associated with irrigation runoff in our field using furrow irrigation. In our example, furrow irrigation results in about $17 \%$ of the applied water as runoff which poses a risk of moving applied chemicals to a surface water ditch and then on to a creek. After evaluating the irrigation runoff risks and reviewing management practices, we will revisit Flowchart 1 to evaluate the risks of applications near surface water, and finally the stormwater runoff risks.

Proceeding to Flowchart 3, the next step is to evaluate IPM practices used to control alfalfa weevil.
Integrated pest management: Egyptian alfalfa weevil

The following was adapted from the UC IPM Alfalfa Pest Management Guidelines available at the UC IPM website, http:// ucipm.ucdavis.edu.

\section{Weevil damage}

Young larvae damage alfalfa by feeding on terminal buds; larger larvae feed on the leaflets. Feeding by older larvae is the most damaging and is characterized as skeletonization and bronzing of the leaves in spring. Under severe pressure, complete defoliation can occur. Damage from weevils is most commonly seen on the first cutting of hay. However, if a second generation occurs, significant damage can result in later cuttings. Adult weevils feed on alfalfa but generally do not cause significant damage.

\section{Weevil monitoring}

Begin monitoring for weevils in early January in southern and central areas of the state. If the alfalfa is too short to sweep, look for signs of feeding damage on the leaves. Sweep fields that have adequate plant height weekly after weevil larvae first appear in late winter or early spring. As the threshold is approached, monitor every 2 to 4 days to determine whether populations decline or a treatment is required. (For details on sweep net sampling, see the UC IPM website, http://ipm.ucdavis.edu.) Research is underway to reevaluate threshold levels, but currently the recommendation is that a treatment is warranted when the weevil larvae count reaches an average of 20 or more larvae per sweep. Continue to monitor weekly during the spring through June (or after a treatment in the Central Valley).

\section{Management options}

Weevil management in alfalfa is focused on the period before the first cutting. Control options are primarily insecticides and early harvest. Biological control is not effective at preventing economic damage in most areas because populations of natural enemies are not sufficient for adequate control in the spring. 
Cultural Control. Depending on the timing of the weevil infestation, cutting the crop after most of the plants have reached the bud stage can sometimes prevent serious damage by the weevil. Most weevils are killed by the harvest and curing process. However, early cutting to control weevils concentrates the survivors in the windrows. Closely monitor alfalfa regrowth for the second cutting to detect feeding damage because both larvae and adults can cause injury.

Organically Acceptable Methods. The primary organically acceptable management method is cutting the crop early if damage seems imminent.

Chemical Control. In our example, Egyptian alfalfa weevil levels have reached the threshold level at a critical period before the first cutting. A chemical control spray is warranted to avoid yield losses due to feeding. After this initial spray, continued monitoring will be needed to determine whether further applications are needed.

\section{Selecting pesticides to reduce water quality risks}

Continuing to work our way through Flowchart 3, the next step is to select an effective control pesticide that has minimum risk to water quality.
Treatment options are derived from the UC IPM Pest Management Guidelines for Weevils (http://www.ipm .ucdavis. edu/PMG/selectnewpest.alfalfa-hay.html) (table 10) combined with the potential for runoff risk and overall runoff risk from table 2 of this publication, which includes three organophosphates, two pyrethroids, and one oxadiazine.

Having read the sections of this publications about the water quality risks associated with various classes of chemicals, we know that many organophosphates are highly water soluble and subject to solution runoff risk, while pyrethroids are highly hydrophobic and adsorb readily to soil sediments that can also be subject to offsite movement at the tail ends of fields where alfalfa stands are often weak. If sediment does not leave the field from pesticide-treated areas, pyrethroids offer a reduced risk to surface waters. The use of indoxacarb offers a similar risk reduction.

\section{Mixing and loading near surface waters}

The next consideration in Flowchart 3 for managing potato aphid is to consider pesticide mixing and loading practices and their impact on surface water quality. The mixing and loading site in our

Table 10. Runoff risk for common treatment options for weevil in alfalfa production

\begin{tabular}{|l|l|l|l|l|l|}
\hline Chemical & Trade name & Chemical class & $\begin{array}{l}\text { Solution runoff } \\
\text { potential }\end{array}$ & $\begin{array}{l}\text { Adsorption runoff } \\
\text { potential }\end{array}$ & Overall runoff risk $^{*}$ \\
\hline chlorpyrifos & Lorsban/Lock-On & organophosphate & high & intermediate & very high \\
\hline cyfluthrin & $\begin{array}{l}\text { Baythroid/ } \\
\text { Renounce }\end{array}$ & pyrethroid & low & intermediate & high $^{* *}$ \\
\hline Indoxacarb & Steward & oxadiazine & low & intermediate & moderate \\
\hline lambda-cyhalothrin & Warrior & pyrethroid & low & intermediate & high \\
\hline malathion & Malathion & organophosphate & intermediate & low & moderate \\
\hline phosmet & Imidan & organophosphate & intermediate & low & moderate \\
\hline
\end{tabular}

Notes:

*Likelihood that the active ingredient will transport from the area of treatment as dissolved chemical in runoff.

t Likelihood that the active ingredient will transport from the area of treatment as attachment to soil or sediment particles in runoff.

${ }^{\ddagger}$ Overall likelihood to cause negative impact on surface water quality as a product of the runoff potential and the aquatic toxicity of the pesticide.

**High in some crops but not in alfalfa production few sediments moving offsite. 
example field is within 50 feet of a surface water ditch. Mixing and loading practices include not overfilling the tank, triple-rinsing containers, and adding the rinsate to the tank for application to the field. When the application is complete, the tank should be rinsed and the rinsate applied to the field. The use of a concrete pad with a catchment sump is also a good solution to reduce risks from mixing and loading near surface water sources.

\section{Irrigation management}

The next step in our assessment in Flowchart 3 is to consider changes in irrigation management. In our example field, runoff to a drainage ditch and nearby creek occurs during irrigation. Potential solutions related to irrigation might include the following.

\section{Irrigation scheduling}

Matching the irrigation applications to crop water use can reduce the applied volume and therefore the amount of runoff. Scheduling using this method applies to both border-check and pressurized irrigation systems; however, the application of the desired amount is much easier with pressurized systems.

\section{Improve irrigation uniformity}

Adjust inflow volume and the cutback time to improve uniformity of infiltration times from the top to bottom of the field. Both may need to be determined on a trial-and-error basis. A balance of uniformity of infiltration times and runoff volume should be the goal.

\section{Reduce runoff volume}

Manage the irrigation system to reduce runoff. Runoff volumes can be reduced in border-check irrigation by matching the inflow rate to the infiltration rate and optimizing the irrigation cutoff point to achieve good uniformity at a reduced runoff volume.

Improve water infiltration. The irrigation water in our example field has a salinity $\left(\mathrm{EC}_{\mathrm{w}}\right)$ of $0.2 \mathrm{dS} / \mathrm{m}$, indicating a "pure water" infiltration problem. Applying gypsum broadcast to be dissolved by the irrigation water would help improve water infiltration, potentially reducing irrigation runoff. Applications are most effective during the part of the season when infiltration problems are most prevalent.
Convert to pressurized irrigation. At sites with runoff risks, changing from surface irrigation to pressurized irrigation is recommended when possible. When properly managed, pressurized irrigation systems cause no irrigation water runoff, effectively reducing the risk of pesticide residue moving offsite.

\section{Runoff water capture and/or recycling}

Sediment basin/runoff recycling. Sediment basins can capture runoff and reduce sediment load. Recycling of runoff waters to the delivery system can completely eliminate the runoff.

Filtering runoff. Overseeding weakened tail ends of alfalfa fields can help reduce soil erosion and help infiltrate runoff water by serving as a vegetated filter strip. Planting vegetation in drains at the tail ends of alfalfa fields (vegetated drainage ditches) will also help to trap sediments and agricultural pollutants.

Runoff water treatment: Landguard. Runoff waters containing organophosphate insecticide residues can be treated with Landguard OP-A, a degradation enzyme, to reduce or eliminate residues in runoff water before water exits the farm.

\section{Application Near Surface Water Risk (Drift)}

Now that we have evaluated the risk of chemical applications near surface water, we go back to Flowchart 1 to evaluate the stormwater runoff risk. Our example field is located near a drainage ditch that contains water draining to a surface water source and is therefore a significant risk; we consider ways of reducing spray drift that could enter the drainage ditch or creek near the example field. Go to Flowchart 5 and refer to the following management options.

\section{Application conditions}

Delay treatments near ditches and surface water bodies until wind is blowing away from these and other sensitive areas.

\section{Application equipment}

Larger droplets are less prone to drift than are smaller droplets. Use as coarse a spray as possible (250-400 microns or larger) without sacrificing canopy coverage. Droplet size is one of the most important factors affecting drift. Use low-drift nozzles that 
produce larger droplet sizes. Fitting a sprayer with air-induction nozzles instead of standard nozzles will reduce spray drift up to $50 \%$ compared with standard nozzles.

\section{Product choice}

Use drift-control or drift-reduction spray additive agents. These materials are generally thickeners that minimize the formation of droplets smaller than 150 microns. They also help produce a more consistent spray pattern and aid in deposition.

\section{Buffer zones}

Maintain adequate buffer areas or zones between the treated site and sensitive areas to ensure that pesticides do not drift from the target area. Read the label as to the size of buffer zone required as related to the rate of active ingredient. Treat buffer zones with materials that are least disruptive to aquatic life.

\section{Change application method}

Air application has a larger drift potential than ground application. Ground application may be preferable to aerial application when there is a risk of drift because a smaller buffer zone is required.

\section{Storm Water Runoff Risk}

Since in the case study the pesticide application occurs in the spring, there is a risk that rainfall will cause soluble residues or sediment to run off to surface water sources. Sediments can contain adsorbed pesticides, most likely pyrethroids. Go to Flowchart 4.

\section{Improve water infiltration}

Chemical amendments used to improve water infiltration

Adding chemical amendments to water or soil can improve water infiltration by improving the chemical makeup of the water or soil. Most chemical amendments work by increasing the total salt concentration and/or decreasing the sodium adsorption ratio (SAR) of the soil-water. Both of these actions enhance aggregate stability and reduce soil crusting and pore blockage.

Calcium materials. Adding calcium (Ca) salts to soil and water increases both the total salinity and soluble calcium. Calcium salts commonly used on alkali (high $\mathrm{pH}$ ) soils include gypsum $\left(\mathrm{CaSO}_{4}\right)$, calcium chloride $\left(\mathrm{CaCl}_{2}\right)$, and calcium nitrate $\left(\mathrm{CaNO}_{3}\right)$. Gypsum is the most common calcium material applied when lowsalt $(E C<0.5)$ water is used. Surface applications are most effective when gypsum is applied at rates equivalent to 1 to 2 tons per acre when water infiltration an issue. One ton of spread gypsum has been effective in improving infiltration for up to 11 inches of lowsalt irrigation water.

Acids and acid-forming materials. Acids are applied to water to dissolve soil lime (the soil must contain lime if acids are used), increasing free calcium in the soil-water matrix and improving infiltration. Commonly applied acid or acid-forming amendments include sulfuric acid $\left(\mathrm{H}_{2} \mathrm{SO}_{4}\right)$ products, soil sulfur, ammonium polysulfide, and calcium polysulfide. Acid materials react with soillime the instant they come in contact with the soil. Sulfurous acid generators, also known as sulfur burners, oxidize elemental sulfur to form sulfur dioxide, which, when combined with water, forms a weak acid that can be injected into irrigation water. When applied to soils, materials with elemental sulfur or sulfides must undergo microbial degradation in order to produce acid. This process may take months or years, depending on the material and particle size (in the case of elemental sulfur). Since these materials form an acid via the soil reaction, they will reduce soil $\mathrm{pH}$ if applied at sufficiently high rates.

\section{Managing soil organic matter to reduce runoff}

Soil organic matter helps stabilize soil aggregates by increasing the number of exchange sites in the soil matrix and encouraging microbial activity. Soil microbes that decompose soil organic matter produce polysaccharides and polyuronides, which act as binders to stabilize aggregates, improving porosity and water infiltration. Over time, continued cultivation and the use of herbicides reduces the organic matter content and aggregate stability of soils. These changes can reduce water infiltration and increase runoff potential.

It is difficult to increase and sustain soil organic matter under the warm, semiarid conditions that prevail in most of California, which favor rapid decomposition of organic matter. Additions of 
organic matter aimed at improving or sustaining aggregate stability and water infiltration must be incremental and continual to be effective. Growers can achieve this in the following ways.

Crop residues. An alfalfa crop already has a fair amount of plant matter that makes its way to the soil surface. However, the residues of rotation crops offer a much greater opportunity to add significant amounts of organic matter. Field crop residues, whether shredded or soil-incorporated, can be left to decompose, adding organic matter and some nutrients to the soil. Crop residue biomass in California's Central Valley ranged from 9,560 pounds per acre for corn following grain harvest to 570 pounds per acre for onions (Mitchell et al. 1999). Even within a specific crop, the biomass contribution can vary. Tomato biomass varied due to harvest date but an intermediate value was 2,880 pounds per acre. Wheat biomass after grain harvest was 4,800 pounds per acre, but if the straw was baled and removed only 670 pounds remained.

Manure and other organic materials. With proper handing and management to avoid the risk of crop contamination by human pathogens, animal manures or compost can help increase soil organic matter content and improve water infiltration. However, the application of manures is currently uncommon due to the limited availability of manures.

\section{Runoff water capture and/or recycling}

\section{Sediment basin/runoff recycling}

Sediment basins can capture runoff and reduce sediment load. Recycling of runoff waters to the delivery system can completely eliminate the runoff.

\section{Filtering runoff}

Overseeding weakened tail ends of alfalfa fields can help reduce soil erosion and help infiltrate runoff water by serving as a vegetated filter strip. Planting vegetation in drainage ditches at the tail ends of alfalfa fields (vegetated drainage ditches) also helps trap sediments and agricultural pollutants.

Runoff water treatment

Alfalfa runoff water can be chemically treated to reduce pesticide residues. This treatment can be done in a tailwater ditch or in a holding basin. Landguard OP-A Enzyme has been shown to be effective for treatment of most soluble organophosphate pesticides. Work is underway to develop enzymes to treat pyrethroid residues, but they are unavailable at this time.

\section{References}

Anderson, B. S., B. M. Phillips, J. W. Hunt, B. Largay, and R. Shihadeh. 2008. Pesticide and toxicity reduction using vegetated treatment systems and Landguard OP-A: Data Summary and Final Report. San Luis Obispo, CA: Central Coast Regional Water Quality Control Board.

Ayers, R. S., and D. W. Westcott. 1985. Water quality for agriculture. United Nations FAO Irrigation and Drainage Paper No. 29, Rev. 1.

Bondarenko, S. J., and J. Gan. 2004. Degradation and sorption of selected organophosphate and carbamate insecticides in urban stream sediments. Environmental and Toxicological Chemistry 23:1809-1814.

Canevari W. M., D Putnam, T. Lanini, R. F. Long, S. Orloff, B. Reed, and R. Vargas. 2000. Overseeding and companion cropping in alfalfa. Oakland: University of California Agriculture and Natural Resources Publication 21594.

Cole, J. T., J. H. Baird, and B. T. Basta. 1997. Influence of buffers on pesticide and nutrient runoff from bermudagrass turf. Journal of Environmental Quality 26:1589-1598.

de Vlaming, V., L. Deanovic, and S. Fong. 2004. Investigation of water quality in agricultural drains in the California Central Valley. Sacramento: California State Water Resources Control Board.

Doorenbos and Pruitt 1997

EPA 2007

Flint, M. L. 1981. Integrated pest management for alfalfa hay. Oakland: University of California Division of Agriculture and Natural Resources Publication 3312. 
Gill, S., F. C. Spurlock, K. S. Goh, and C. Ganapathy. 2008. Vegetated ditches as a management practice in irrigated alfalfa. Environmental Monitoring and Assessment 144:261-267.

Hanson, B. and L. Schwankl. 1995. Surface irrigation. Water Management Series Publication 94-01. Davis: University of California Irrigation Program, UC Davis Department of Land, Air and Water Resources.

Hanson, B. R., K. M. Bali, and B. L. Sanden. 2008. Irrigating alfalfa in arid regions. Chapter 7 in C. G. Summers and D. H. Putnam, eds, Irrigated alfalfa management in Mediterranean and desert zones. Oakland: University of California Agriculture and Natural Resources Publication 8292, http://alfalfa.ucdavis.edu/IrrigatedAlfalfa/pdfs/ UCAlfalfa8293Irrigation_free.pdf.

Karkoski, J. 2008. Management plan. San Joaquin County Delta Water Quality Coalition, Central Valley Regional Water Quality Control Board, September 30, 2008.

Long, R., M. Nett, D. H. Putman, G. Shan, J. Schmiere, and B. Reed. 2002. Insecticide choice for alfalfa may protect water quality. California Agriculture 56(5): 163-169.

Long, R. F., J. Gan, and M. Nett. 2005. Pesticide choice: Best management practice (BMP) for protecting surface water in agriculture. Oakland: University of California Agriculture and Natural Resources Publication 8161, http://ucanr.org/freepubs/docs/8161.pdf.

Long, R. F., A. Fulton, and B. Hanson. 2010a. Protecting surface water from sediment-associated pesticides in furrow-irrigated fields. Oakland: University of California Agriculture and Natural Resources Publication 8403, http://anrcatalog.ucdavis.edu/pdf/8403.pdf.

Long, R. F., B. R. Hanson, A. E. Fulton, and D. Weston. 2010 b. Mitigating offsite movement of pyrethroid insecticides in furrow-irrigated fields in the Central Valley. California Agriculture. 64(3): 135-140.
Markle, J. C. 2009. Efficacy of settlement ponds for reducing pyrethroid runoff in almond orchards. Almond Board of California Final Research Report. CURES website, http://www.curesworks.org/bmp/retentionPondStudy.pdf.

Mitchell, J. P., T. Hartz, S. Pettygrove, D. Munk, D. May, F. Menezes, J. Diener, and T. O’Neill. 1999. Organic matter recycling varies with crops grown. California Agriculture 53(4):37-40.

Moore, M. T., E. R. Bennet, C. M. Cooper, R. W. Smith, F. D. Shields, C. D. Milam, and J. L. Farris. 2001. Transport and fate of atrazine and lambda-cyhalothrin in a vegetated drainage ditch in the Mississippi Delta. Agriculture Ecosystems and Environment 87:309-314.

Moore, M. T., D. L. Denton, C. M. Cooper, J. Wrysinski, J. L. Miller, K. Reece, D. Crane, and P. Robins. 2008. Mitigation assessment of vegetated drainage ditches for collecting irrigation runoff. Journal of Environmental Quality 37:486-493.

\section{NRCS 2007}

PAN (Pesticide Action Network) pesticide database 2008, http://www.pesticideinfo.org/.

Prichard, T. L., and R. Antinetti. 2009. Managing organophosphate pesticide residues using degradation enzymes. Proceedings, American Society of Agronomy, California Plant and Soil Conference.

Schulz, R., 2004. Field studies on exposure, effects, and risk mitigation of aquatic nonpoint-source insecticide pollution: A review. Journal of Environmental Quality 33:419-448.

Schwankl, L. J., and T. L. Prichard. 2009. Soil-based irrigation monitoring. http://ucmanagedrought.ucdavis.edu/smm.cfm.

Schwankl, L., T. Prichard, and B. Hanson. 2007. Reducing runoff from irrigated lands: Tailwater return systems. Oakland: University of California Agriculture and Natural Resources Publication 8225, http://anrcatalog.ucdavis.edu/ SoilWaterIrrigation/8225.aspx. 
Singer, M., J. D. Oster, A. Fulton, W. Richardson, and T. Prichard. 1992. Water penetration problems in California soils:

Diagnoses and solutions. Davis: University of California, Davis, Kearney Foundation of Soil Science.

Sojka, R. E., D. L. Bjorneberg, J. A. Entry, R. D. Lentz, and W. J. Orts. 2007. Polyacrylamide in agriculture and environmental land management. Advances in Agronomy 92:75-162.

Trout, T. J., R. E. Sojka, and R. D. Lentz. 1995. Polyacrylamide effect on furrow erosion and infiltration. Transactions of the ASAE 38:761-765.

Watanabe, H., and M. E. Grismer. 2001. Diazinon transport through inter-row vegetative filter strips: Micro-ecosystem modeling. Journal of Hydrology 247: 183-199.

Weston, D. P., R. D. Lentz, M. D. Cahn, A. K. Rothert, and M. J. Lydy. 2009. Toxicity of various anionic polyacrylamide formulations when used as erosion control agents in agriculture. Journal of Environmental Quality 38:238-247.

Weston, D. P., and C. J. Jackson. 2010. Use of engineered enzymes to identify organophosphate and pyrethroid-related toxicity in toxicity identification evaluations. Environmental Science and Technology 44(5): 1713-1719.

Weston, D. P., and M. J. Lydy. 2010. Urban and agricultural sources of pyrethroid insecticides to the Sacramento-San Joaquin Delta of California. Environmental Science and Technology 44(5): 1833-1841.

\section{ACKNOWLEDGMENTS}

This publication was prepared as a Component of California Department of Pesticide Regulation-Pesticide Management Alliance grant in cooperation with the San Joaquin County and Delta Water Quality Coalition. Funding for this publication has been provided in part through a grant awarded by the California Department of Pesticide Regulation in cooperation with the San Joaquin County and Delta Water Quality Coalition, and the Stockton East Water District.

\section{Measurement Conversion Table}

\begin{tabular}{|c|c|c|c|}
\hline U.S. Customary & $\begin{array}{c}\text { Conversion factor } \\
\text { for U.S. Customary } \\
\text { to Metric }\end{array}$ & $\begin{array}{l}\text { Conversion factor } \\
\text { for Metric to U.S. } \\
\text { Customary }\end{array}$ & Metric \\
\hline \multicolumn{4}{|l|}{ Length } \\
\hline inch (in) & 2.54 & 0.394 & centimeter $(\mathrm{cm})$ \\
\hline foot $(\mathrm{ft})$ & 0.3048 & 3.28 & meter (m) \\
\hline mile (mi) & 1.61 & 0.62 & kilometer (km) \\
\hline \multicolumn{4}{|l|}{ Area } \\
\hline acre (ac) & 0.4047 & 2.47 & hectare (ha) \\
\hline square foot $\left(\mathrm{ft}^{2}\right)$ & 0.0929 & 10.764 & square meter $\left(\mathrm{m}^{2}\right)$ \\
\hline \multicolumn{4}{|l|}{ Volume } \\
\hline fluid ounce (fl oz) & 29.57 & 0.034 & milliliter (ml) \\
\hline pint, liquid (pt) & 0.473 & 2.11 & liter (I) \\
\hline pint, dry (pt) & 0.55 & 1.82 & liter (I) \\
\hline quart, liquid (qt) & 0.946 & 1.056 & liter (I) \\
\hline quart, dry (qt) & 1.1 & 0.91 & liter (I) \\
\hline gallon (gal) & 3.785 & 0.26 & liter (I) \\
\hline inch (in; irrigation) & 305 & 0.00328 & millimeter \\
\hline acre-inch (ac-in) & 102.8 & 0.0097 & cubic meter $\left(\mathrm{m}^{3}\right)$ \\
\hline acre-foot (ac-ft) & 1,233 & 0.000811 & cubic meter $\left(m^{3}\right)$ \\
\hline cubic foot $\left(\mathrm{ft}^{3}\right)$ & 28.317 & 0.353 & liter (I) \\
\hline cubic yard (yd³) & 0.765 & 1.307 & cubic meter $\left(\mathrm{m}^{3}\right)$ \\
\hline gallon per acre & 9.36 & 0.106 & liter per hectare (I/ha) \\
\hline \multicolumn{4}{|l|}{ Mass } \\
\hline ounce (oz) & 28.35 & 0.035 & gram (g) \\
\hline pound (lb) & 0.454 & 2.205 & kilogram (kg) \\
\hline $\operatorname{ton}(\mathrm{T})$ & 0.907 & 1.1 & metric ton $(\mathrm{t})$ \\
\hline $\begin{array}{l}\text { pound per acre } \\
\text { (lb/ac) }\end{array}$ & 1.12 & 0.89 & $\begin{array}{l}\text { kilogram per hectare } \\
\text { (kg/ha) }\end{array}$ \\
\hline ton per acre (T/ac) & 2.24 & 0.446 & $\begin{array}{l}\text { metric ton per } \\
\text { hectare }(\mathrm{t} / \mathrm{ha})\end{array}$ \\
\hline
\end{tabular}


To order or obtain ANR publications and other products, visit the ANR Communication Services online catalog at http://anrcatalog.ucanr.edu/ or phone 1-800-994-8849. You can also place orders by mail or FAX, or request a printed catalog of our products from

University of California

Agriculture and Natural Resources

Communication Services

1301 S. 46th Street

Building 478 - MC 3580

Richmond, CA 94804-4600

Telephone 1-800-994-8849

510-665-2195

FAX 510-665-3427

E-mail: anrcatalog@ucanr.edu

(C)2016 The Regents of the University of California. This work is licensed under the Creative Commons Attribution-NonCommercial-NoDerivatives 4.0 International License. To view a copy of this license, visit http://creativecommons.org/licenses/by-nc-nd/4.0/ or send a letter to Creative Commons, PO Box 1866, Mountain View, CA 94042, USA.

Publication 8459

ISBN-13: 978-1-60107-846-9

The University of California, Division of Agriculture and Natural Resources (UC ANR) prohibits discrimination against or harassment of any person in any of its programs or activities on the basis of race, color, national origin, religion, sex, gender, gender expression, gender identity, pregnancy (which includes pregnancy, childbirth, and medical conditions related to pregnancy or childbirth), physical or mental disability, medical condition (cancer-related or genetic characteristics), genetic information (including family medical history), ancestry, marital status, age, sexual orientation, citizenship, status as a protected veteran or service in the uniformed services (as defined by the Uniformed Services Employment and Reemployment Rights Act of 1994 [USERRA]), as well as state military and naval service.
UC ANR policy prohibits retaliation against any employee or person in any of its programs or activities for bringing a complaint of discrimination or harassment. UC ANR policy also prohibits retaliation against a person who assists someone with a complaint of discrimination or harassment, or participates in any manner in an investigation or resolution of a complaint of discrimination or harassment. Retaliation includes threats, intimidation, reprisals, and/or adverse actions related to any of its programs or activities.

UC ANR is an Equal Opportunity/Affirmative Action Employer. All qualified applicants will receive consideration for employment and/or participation in any of its programs or activities without regard to race, color, religion, sex, national origin, disability, age or protected veteran status.

University policy is intended to be consistent with the provisions of applicable State and Federal laws.

Inquiries regarding the University's equal employment opportunity policies may be directed to: John Sims, Affirmative Action Contact and Title IX Officer, University of California, Agriculture and Natural Resources, 2801 Second Street, Davis, CA 95618, (530) 750-1397. Email: jsims@ucanr.edu. Website: http://ucanr.edu/sites/anrstaff/Diversity/Affirmative_ Action/.

An electronic copy of this publication can be found at the ANR Communication Services catalog website, http://anrcatalog.ucanr.edu/.

UC This publication has been anonymously peer reviewed for technical accuPEER racy by University of California scientists and other qualified professionals. REVIEWED This review process was managed by the ANR Associate Editor Chair.

web-9/16-SB/CR 
FC1

Assessing the Risk of Offsite Movement of Ag Chemicals

to Surface Waters

Follow the decision tree from each shaded box below to assess risk, based on your conditions. If the risk is significant, continue on to view management practices that

may reduce the risk of offsite movement
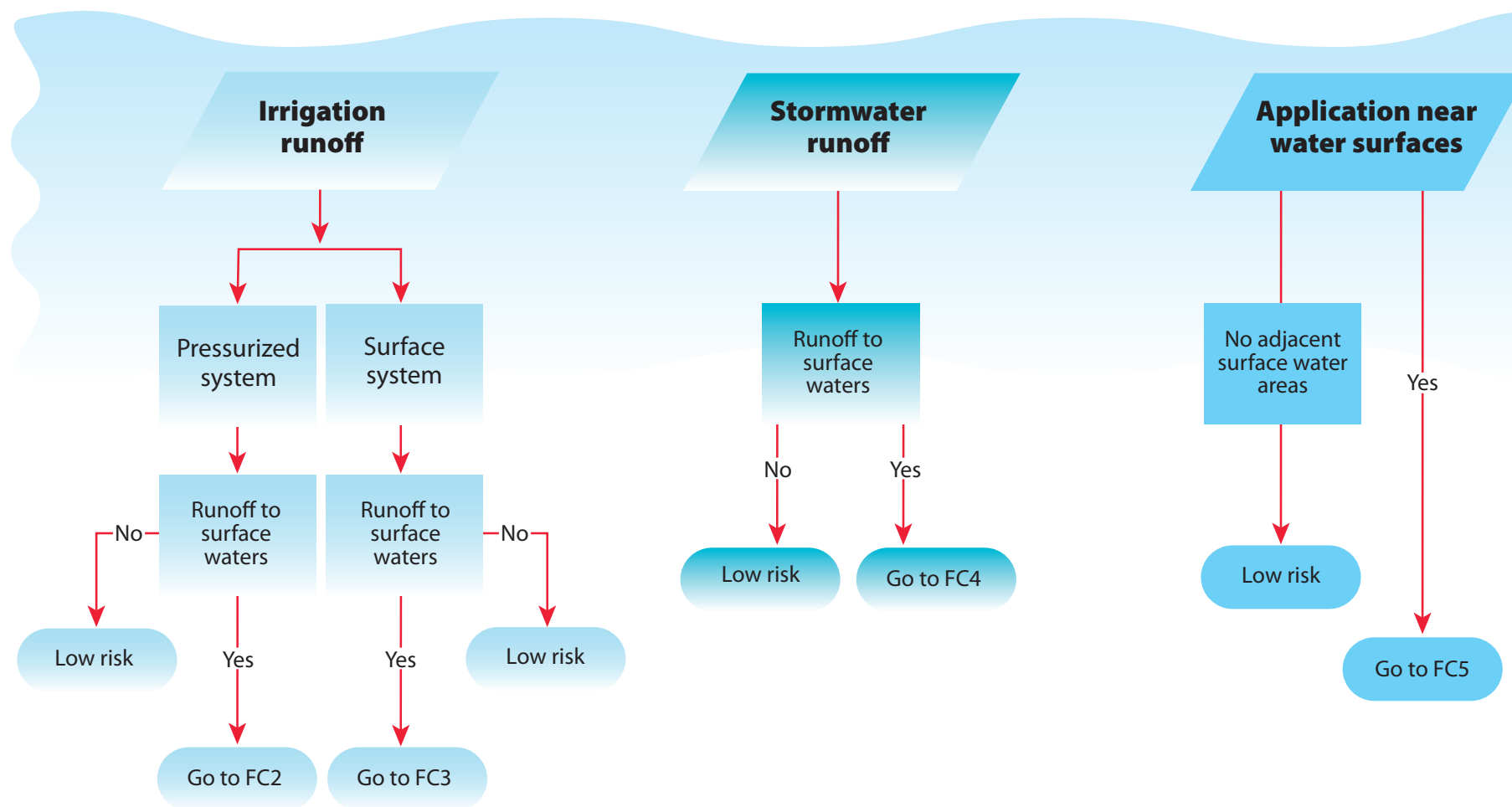


\section{FC2}

\section{Reducing the Risk of Offsite Movement of Ag Chemicals} in Runoff - Pressurized Irrigation Systems

Runoff to surface waters occurs

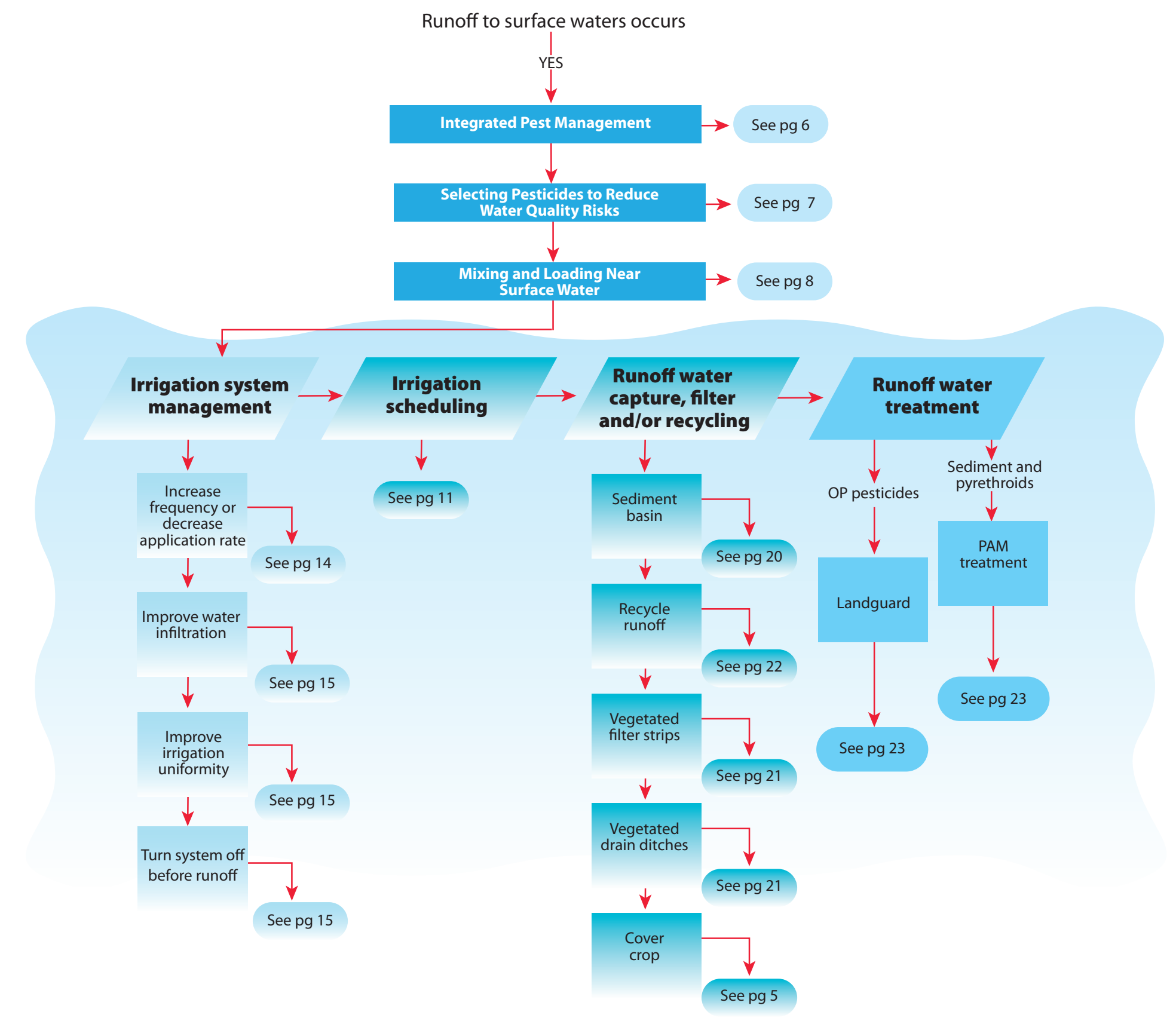




\section{FC3}

Reducing the Risk of Offsite Movement of Ag Chemicals

in Runoff - Surface Irrigation Systems

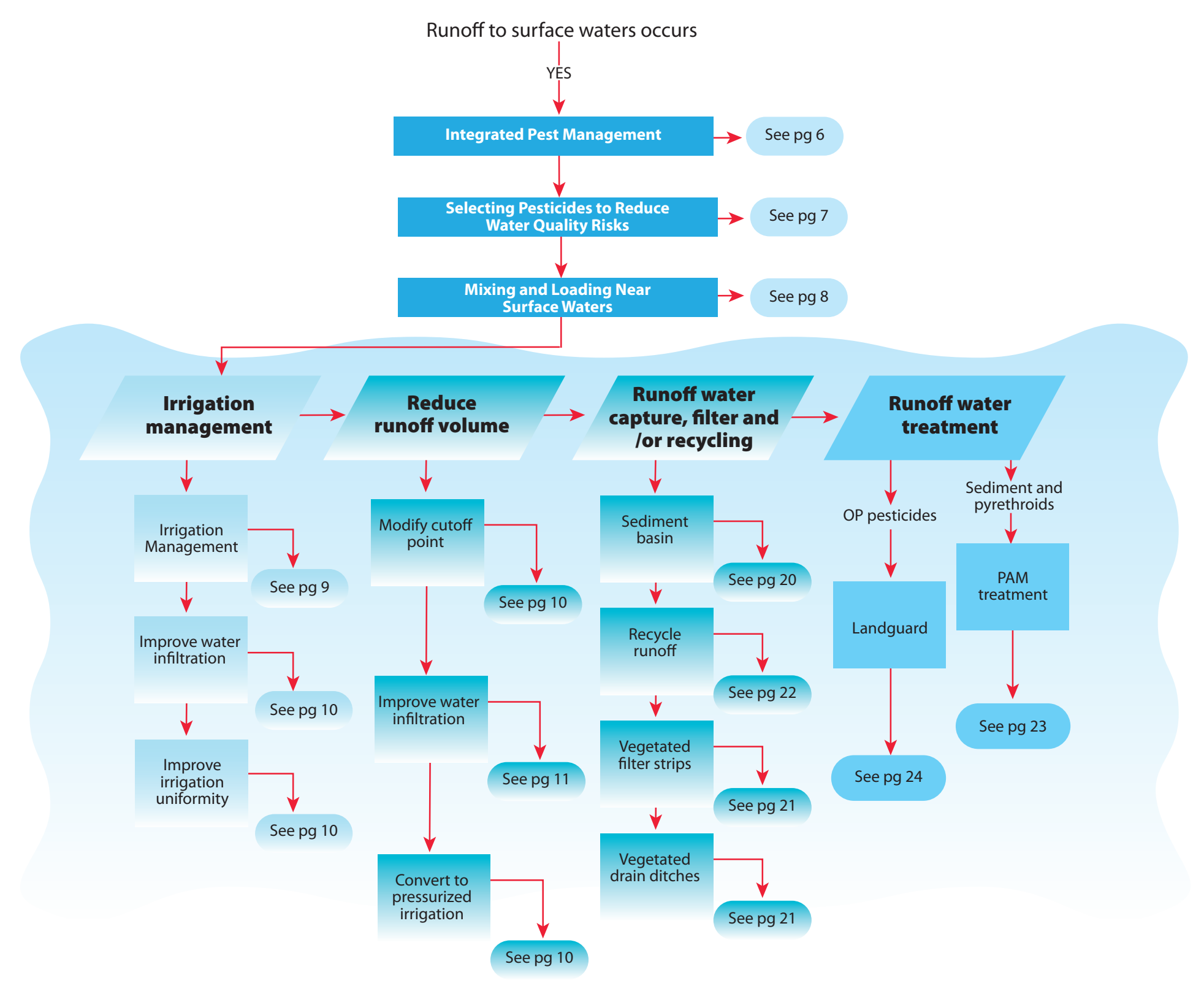




\section{FC4}

Reducing the Risk of Offsite Movement of Ag Chemicals

in Stormwater Runoff

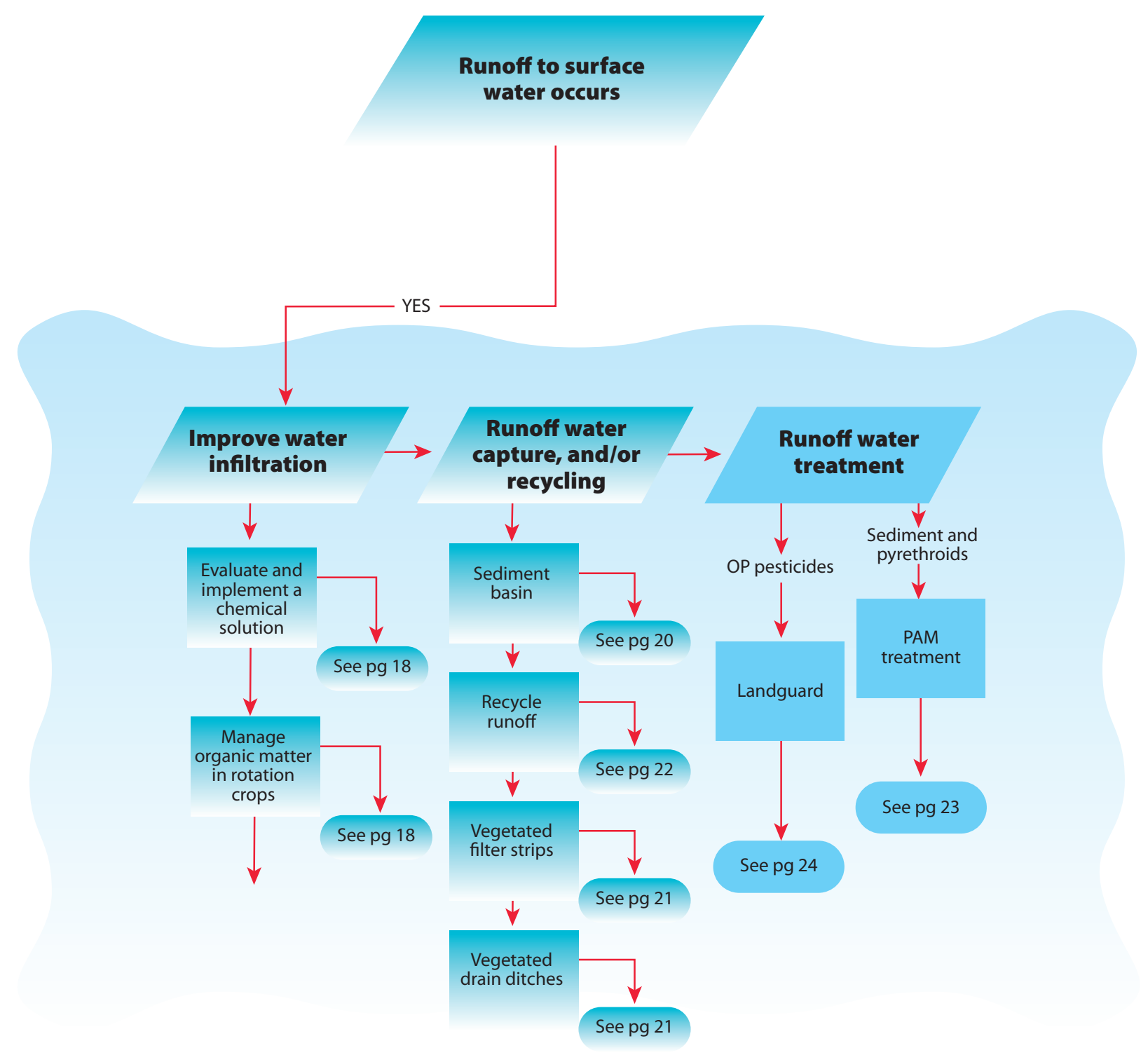




\section{FC5}

Reducing the Risk of Offsite Movement of Ag Chemicals Near Water Surfaces in Drift Situations

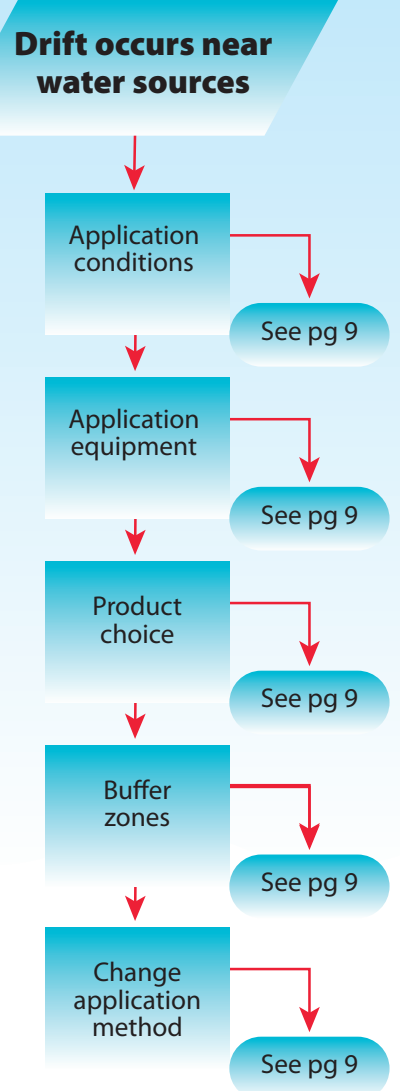

